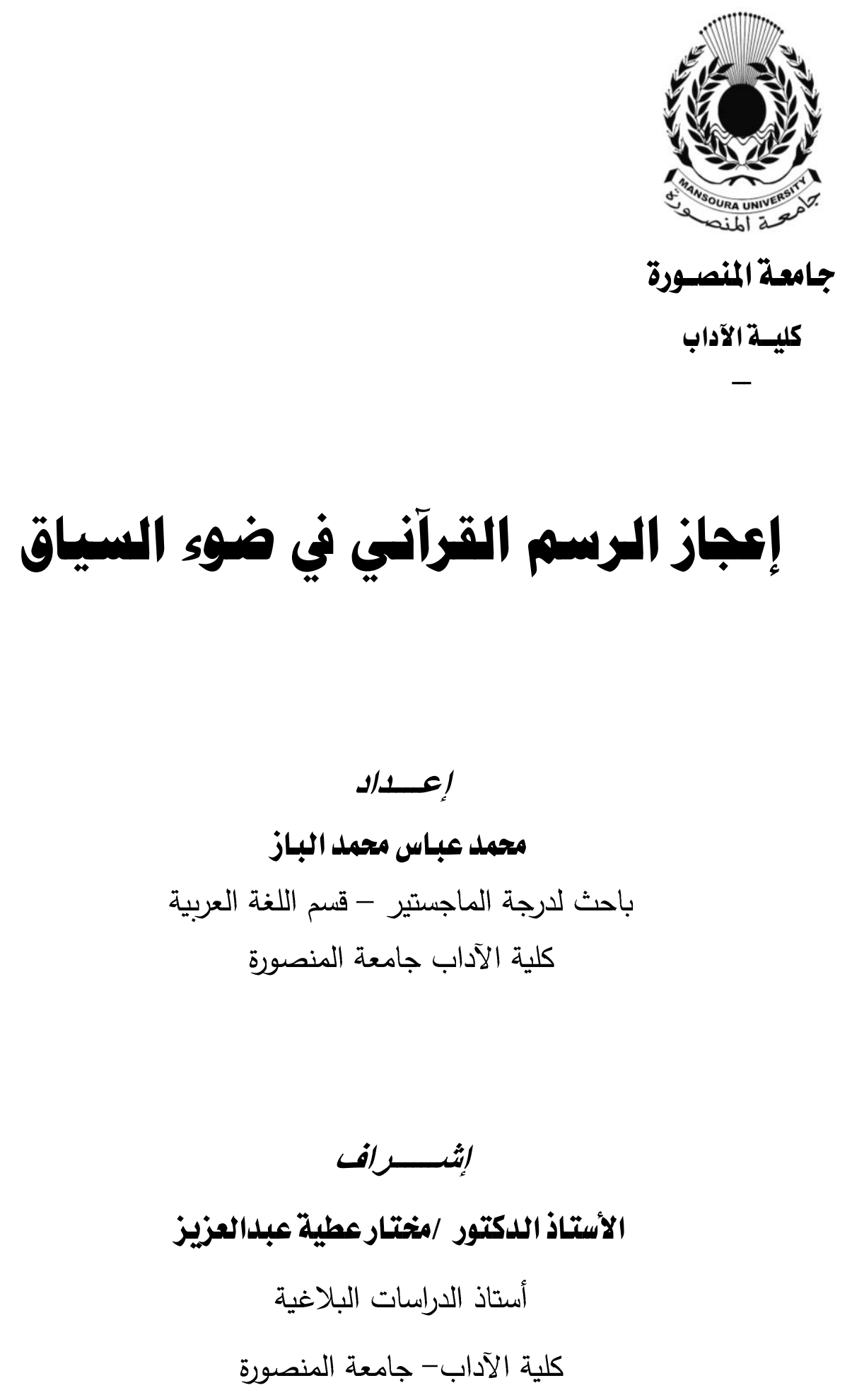




\section{إعجاز الرسم القرآني في ضوء السياق}

\section{محمد عباس محمد الباز}

بلهث لدرجة الملجستير -قسم اللغة العربية

$$
\text { كلية الآداب جامعة المندورة }
$$

ملخص البعث:

يتناول الباحث هذا المبحث:حذف بعض الأحرف من الرسم القرآني والدلالة البلاغية في ضوء السياق لحذف هذه الأحرف من الرسم القرآنسي

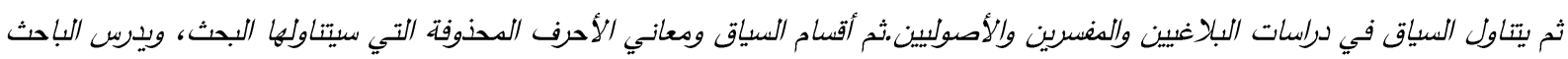
البن البناء المراكثي وآراءه في الحذف من الرسم القرآني، ثم وقفة لابد منها ليبين الباحث الطريقة التي سينهجها.

\section{Abctract :}

The researcher deals with this topic: removing some letters from the Quranic drawing and rhetorical significance in light of the context to remove these letters from the Quranic drawing.

Then he deals with context in the studies of rhetoric, interpreters and fundamentalists. Then sections of the context and the meanings of deleted letters that will be addressed by the research, and the researcher studies Ibn Al-Bana Al-Marrakchi and his views on the deletion of the Quranic drawing, then a pause that is necessary to show the researcher the way he will approach.

$$
\text { وهذه أمثلة لبض الكلمات القرآنية التي حذف }
$$

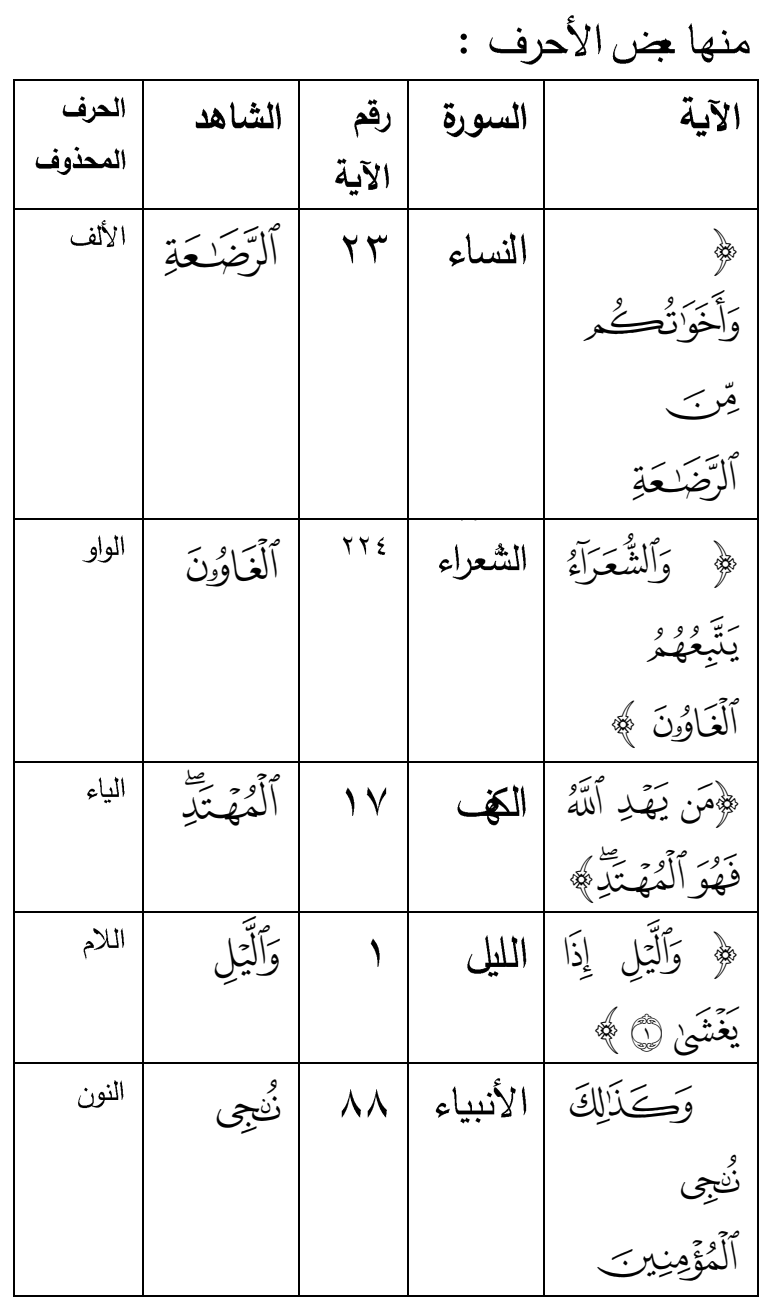

(1) حذف بعض الأحرف مز الربسم القرآذي ..

\section{أنموذجا:}

إن المتأمل في الرسم القرآني يجد أنه قد كن في بض مواضعه بطريقة تخط القواعد الإملائية،

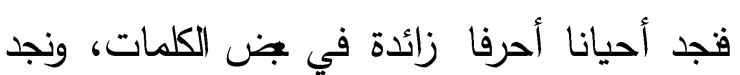
أحيانا أخىى أحرفا محذوفة من بض الكلمات .وهذه الأحرف المحذوفة من بض كلمات الرسم القرآني، ليس لحذفها علة نحوية أو صرفية.

وقد تحدث عنه الإمام السيوطي وأطلق عليه مسمى مسمى حذف الاقطاع، فقال:(لحذف على أذواع،

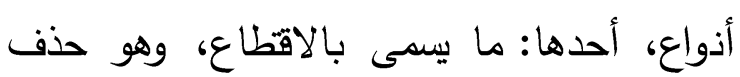

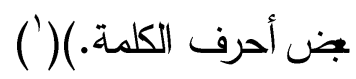

وهذا الرسم القرآني أقره لهحابة - رضي الله عنهم - وتلقته الأمة بالقبول إلى يومنا هذا. (') معترك الأقران في إعجاز القرآن، جلال الدين

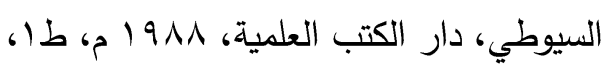




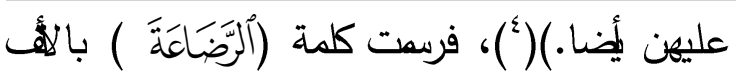

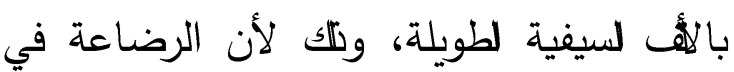

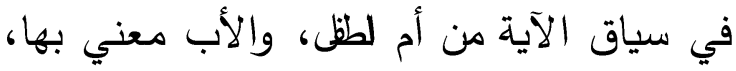
فالأب هو اتي ينفق، والأم هي التي حملته والته وولدته وأرضعته، فهي رالي رضاعة أصلية

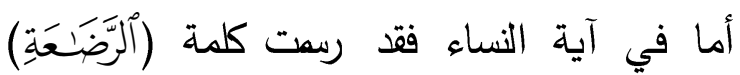
بالأف لتجرية الصيرة، وذلك لأن الرضاعة في التهاء

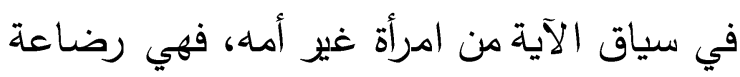
رضاعة تبعية غير أصلية.

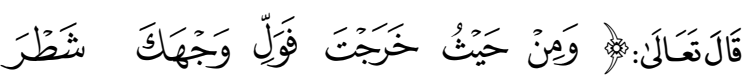

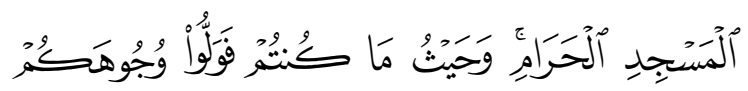

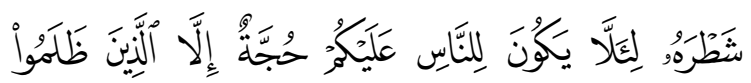

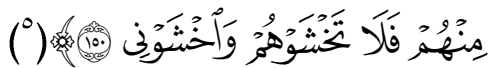

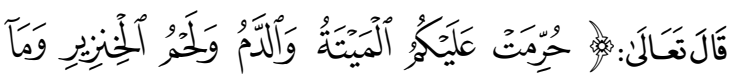

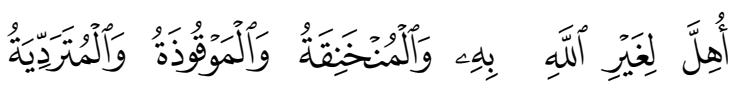

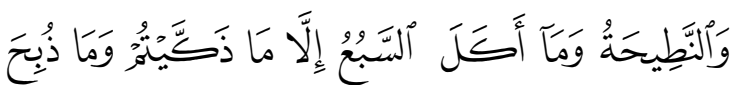

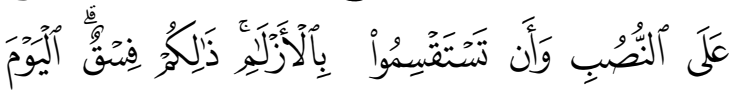

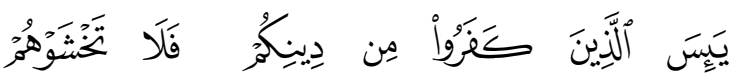

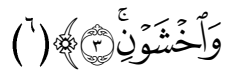

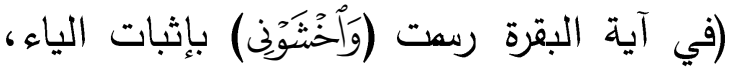

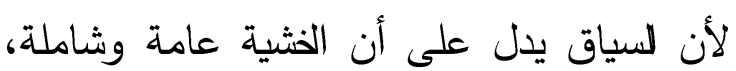

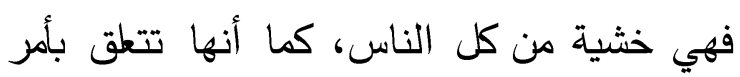

(") روح المعاني في تفسير القرآن العظيم والسبع العبا

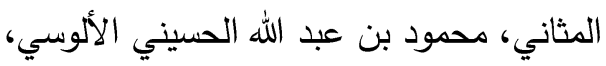

المحقق: علي عبد الباري عطية، دار الكتب الكبان الكبان

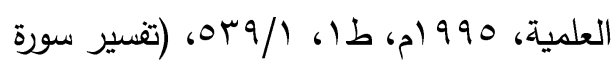

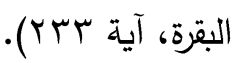

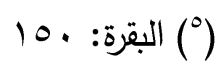

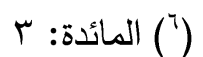

(r) الدلالة البلاغية في ضوء السياق لحذف

بعض الأحرف من الرسم القرآني . .

جاء السياق في القرآن الكريم مؤكدا على القيمة البلاغية لحذف جض الأحرف من الرسم القرآني،

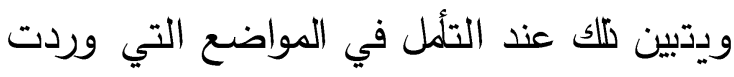
فيها فس الكلمة في سياقات مختلفة. فند المولى عز وجل يضع هذه الكلمات وضعا في غاية الدقة والإحكام والجمال، ونجد الَّولى عز وجل يجمع بين

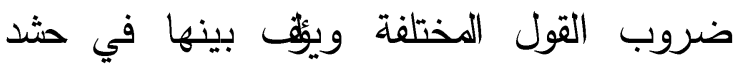
عيب، لا يملك المتأمل في هذا الكتاب العظيم إلا أن يخر ساجدا لله رب العالمين.

وهذه أمثلة للدلاكة البلاغية في ضوء السياق لدفف بعض الأحرف:

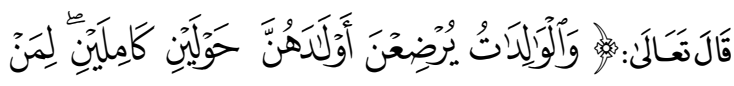

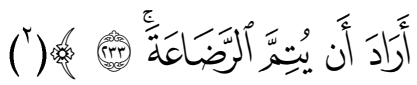

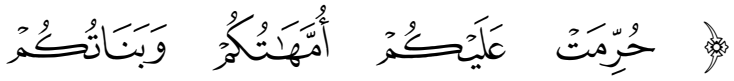

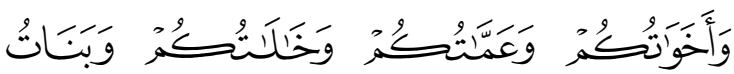

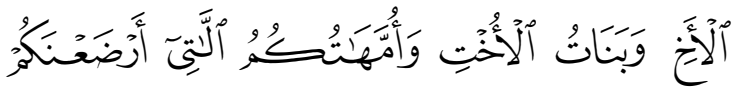

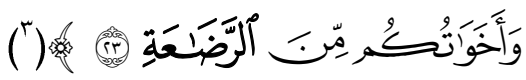
في آية البقرة، قال الآلوسي:( لهن أراد إتمام

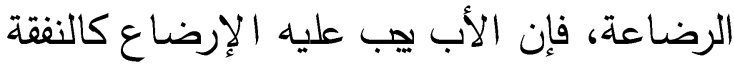

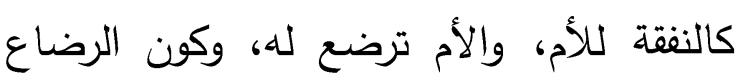

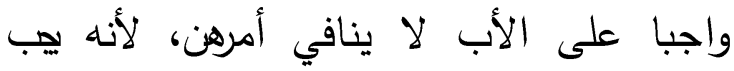


الأسلوب لحيث في الإيمان بوجود طرق مختلفة مختلفة للتعبير عن المعنى، وأن الكتب أولثاعر لهن

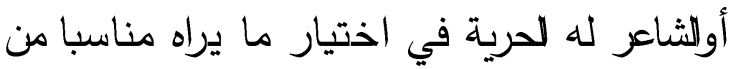

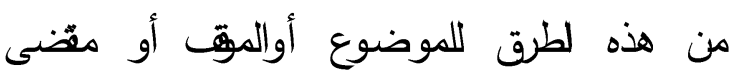

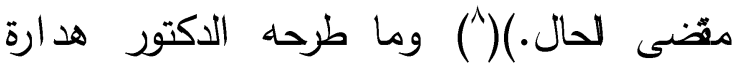

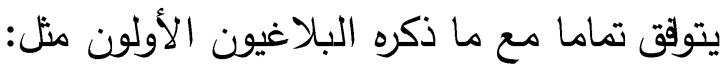
مثل: لجلطظ وعبد القاهر وغيرهما من موافقة الكلام لكمّىى لحال، وهذا هو سياق الدقام.

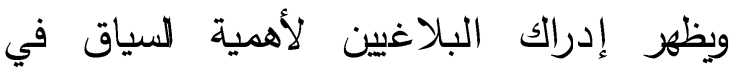
اشتراطهم مطابقة الكلام لمقتىى لحال، واشتهرت

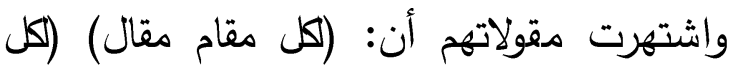
كلمة مع صاحبتها مقام.)(") فلا يضر المعنى على السياق اللغزي (المقال)، بل (المقال)، بل يتجاوزه إلى سياق لحال (المقام).

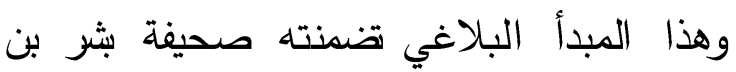
المعتمر، التي نقل لجلطظ قوله:(المعنى ليس يشرف

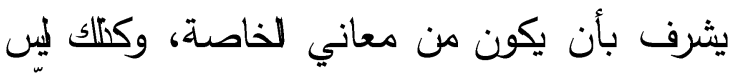

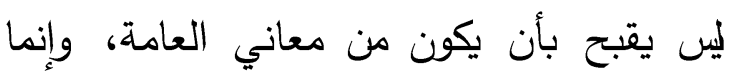

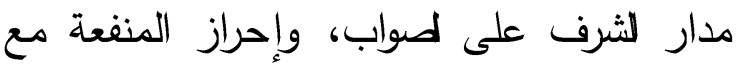

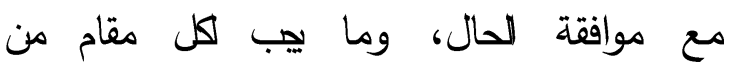

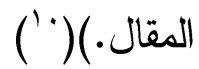
وقد استقرأ الدكتور تمام حسان تاريخ البلاغة العربية، وقارن بينه ويبن ما يدعيه اللغويون

( ) الأسلوبية والأسلوب، محمد مصطفى هدارة، دار العلوم

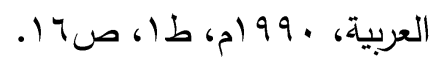

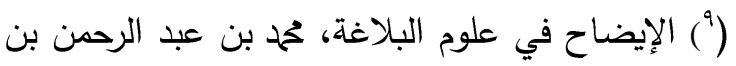

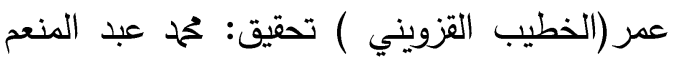

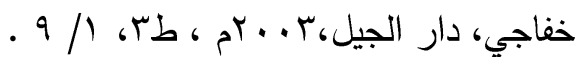
(') البيان والتبيين، عمرو بن بحر الجاحظ، تحقيق الجيق

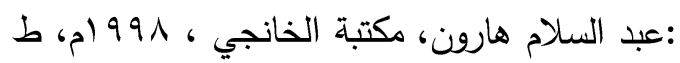

عقي من طب العبادة، وهو تحويل القبلة، أما في

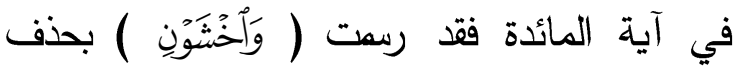
الياء، لأن السياق يدل على أنها خثية خاصة

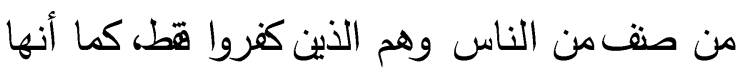

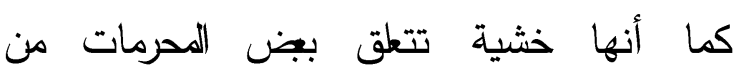

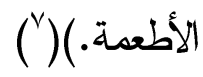

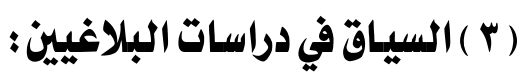
لقد اهتم البلاغيون بدراسة السياق قديما وحديثا، فأفرد له القدماء أبوابا فُصولا في مؤلفاتهج، مثل: لجلظ والعككي والسكاكي، وغيرهم.

وفي الصر لحيث أُفردت مؤلفات خاصة لدراسة السياق وأثره في صناعة البلاغة العربية، بل لبك

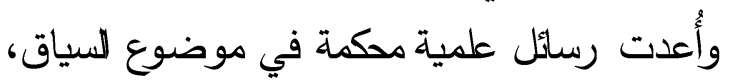
مثل: (دلالة السياق، للبلث: ردة الله بن ردة بن فئل

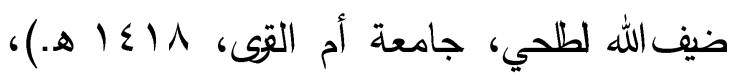
وكتاب: (علم الدلالة، للاكتور أحمد مختار عمر، دار عالم الكب، 911 (م)، وكتاب:( دلالة الألة الألفلظ، للدكتور إبراهيم أني، مكتبة الأنجو

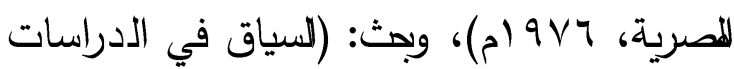
البلاغية والأصولية، للدكتور أسامة عبد العزيز جاب اللها بث مثثور بجلة الدراسات الإسانية

$$
\text { والأدبية، عدد يوليو } 99 \text { • rم. }
$$

وربط العلماء والدارسون ين السياق وبين الأسلوبية، فهذا الأستاذ الكتورتحمحطفى هد ارة،

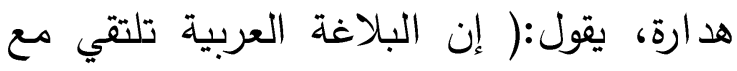
(') إعجاز الرسم القرآني بين المثبتين والمنفين، نثمة بنت عبدالله الطوالة،بحث منشور بمجلة الدراسات

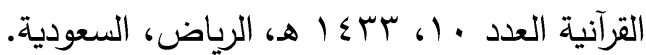


بالقرئن لسياقية المختلفة، كما يثيع لتك في

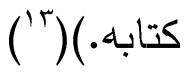
وقد عقد لجلحظ في البيان والتبيين مبحثا عن

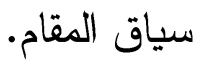
(كما كان كلامه عن تمييز أصناف الدلالات على على المعاني مدخلا لتمييز أساليب الدلالة على لميل

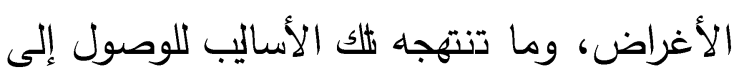

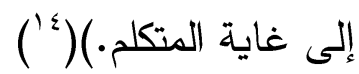
يقول لجلحظ: ( أصناف الدلالات على المعاني من لذظ وغير لظ خسة : أولها اللظ ، ثم الإثدارة الإشارة ، ثم العقد، ثم لخطه ثم لحال التي تتمى تسمى نصبة. والصبة هي الحال الدالة التي تقوم

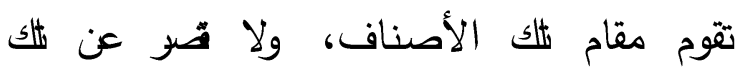
الالالات، ولكل واحد من هذه لذمة صدورة بائنة بائنة عن صدورة صاحبتها، وحلية مخالفة لحلية أختها، وهي التي تئف عن أعيان المعاني في لجملة، ثم عن حقائقها في الثقسير، وعن أجناسها أجناسها وأقدارها، وعن خاصها وعامها، وعن

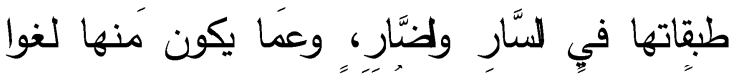

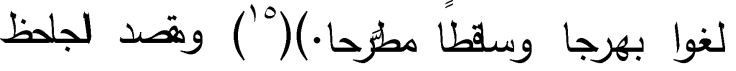
لجلحظ هنا من (لحال): الدلالة على ملمح للياق السياق التي هو مناط الأمر في عناصر الرسالة الرسالة الكلامية، فهو يقول: (وأما الصُّبة، فهي فهي لحال الناطقة بغير اللظظ والمشيرة بغير اليد.(17)
الغربيون من أن فكرة مراعاة المقام فكرة حديثة، حديثة، وهي من مغامرات العقل المعاصر • يقول من ان يقول الدكتور تمام حسان:(وقد كان البلاغيون عند اعترافهم بفكرة المقام متقدمين لُ سنة سنة تقريبا على زمانهم، لأن الاعتراف بفكرتي المقام المقام أوالمقال بوصفهما أساسين متميزين من لُٔس لُٔس تحليل المعنى يـ ع.دٌ الآن في الغرب من الكثوف التي جاءت نديجة لمغامرات العقل المعاصر في دراسة اللغة.)(' (') وقد اهتم البلاغيون بملمح للسياق وعدوه أصلاً لما يمن أن توصله الرسالة اللغوية، وتنوت تعليقاتهم حول لسياق في إطار بحوثهم المختلفة

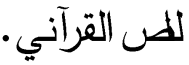
فهذا أبو عبيدة معر بن المثنى ( . M هـ (1) ) يثير إلى الكيفية التي يتت التوصل بها إلى فهم المعاني القرآنية و وإدراك دلالاتها المتنوعة الثرية، وتلك هب لسياق الني ترد فيه، وكان تلاك

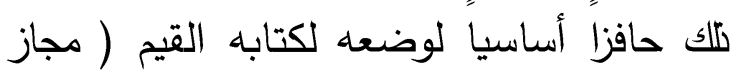
القرآن) أو كما تصده بأنه ( لطرق التي يسلكها يسلكها القرآن في تعبيراته.)( (وقد عمد أبو عبيدة إلى تبيان ثلك لطرق لخاصة لخاصة لأداء المعاني، والدلالات في للسياق القرآني، ببيان لإياق الالالي لها، عنطريق ثُير ثقيير الكلمة اللغوية التي تحتاج إلى ثقيير بالقرئن

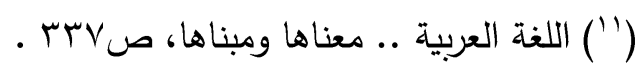

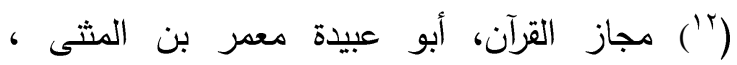

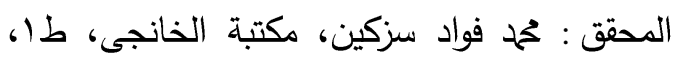

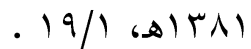


الكريم هو ألظم كتاب راعى هذه الهألة، كما سيضح نلك فيفول البث التالية.

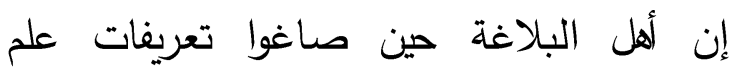
البلاغة اعتمدوا على وجهات نظر متعددة لهذه التعريفات. فمنهم من راعى جلب المتكلم (المرسل

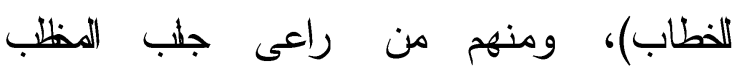

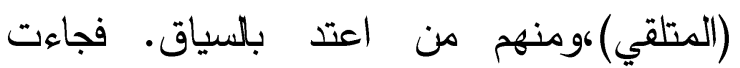

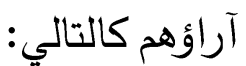

أولا: من علماء البلاغة من راعى جانب المتكلّم

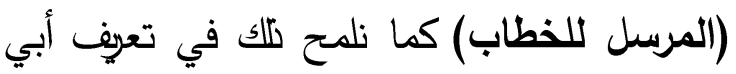

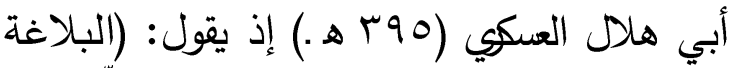

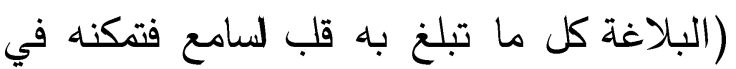

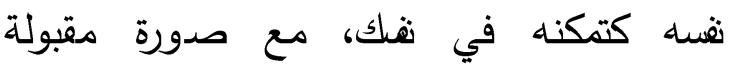
ومعرض حنن.)("19)،فالعسكي يركز على أمرين:

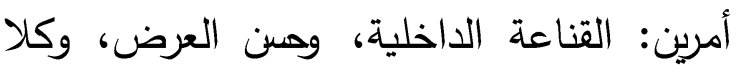

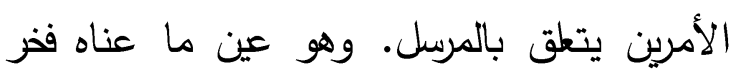

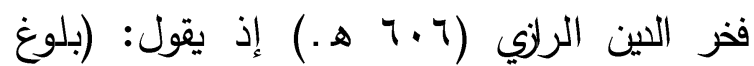
الرجل بعبارته كنه ما في قلبه مع الاحتراز

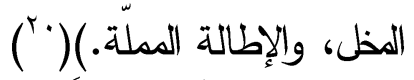

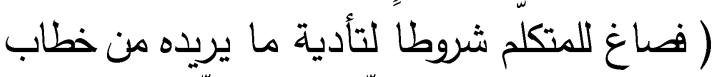
خطاب إلى المتلقي، فركز على تككن المعنى في

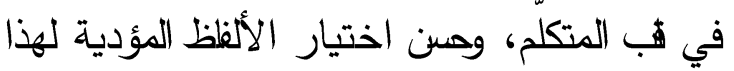
لهذا المعنى، مع مراعاة عدم الإسراف التعبيزي

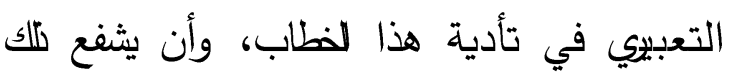

(9919) كتاب الصناعتين: الكتابة والثعر، ص • (1.

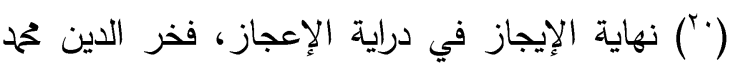

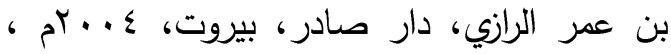

ويؤكد لجلظ على أن مدار الأمر في عملية التواصل اللغزي بكل أبعاده يتحدد في هسن اختيار الجار الإني

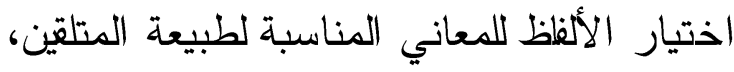
فيقول: ( كل ضرب من لحيث ضرب من اللظه

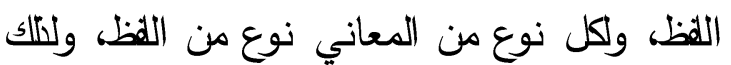
ولنلاك يب إفهام كل قوم بمقدار طاقته، ولمثل

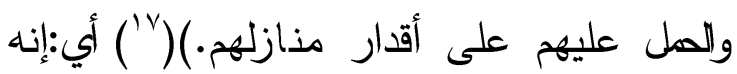
يب عند صياغة الرسالة اللغوية مراعاة أحوال أحوال المتلين، وبيئة التلقي (سياقه )، حتى التى تؤتي الرسالة ثمارها المرجوة.

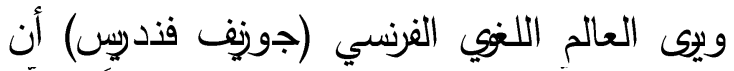
فندريس) أن معنى الكلمة يتم تعديله وفقا لتعدد السياقات التي تقع فيها الكلمة، فتكون الكلمة

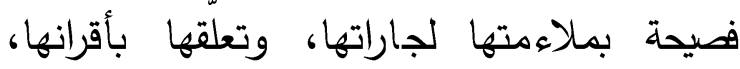
وارتبطها بهم عضويا في نظم بديع لا ترضى به بهاه

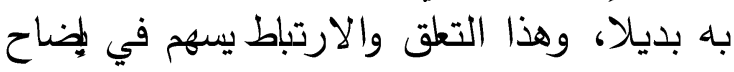

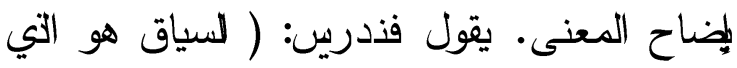
التي يفرض قيمة واحدة بعينها على الكلمة بالرغم من الدعاني المتعددة التي في وسعها أن تدل عليها، ولسياق لئضا هو التي يخلق لها قيمة فئن قيمة هضورية.)(

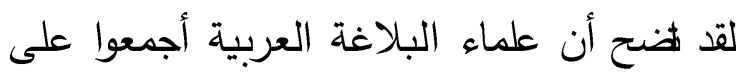
على أهمية السياق في فهم وتحديد معنى الكلمة،

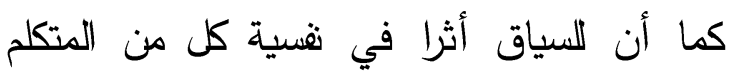
والمتلقي. ومن السياق، ارتفاع لهجة الخطاب

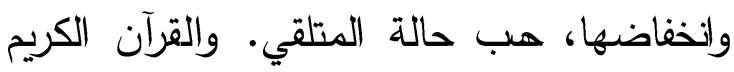

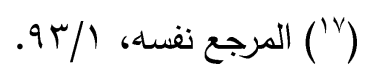

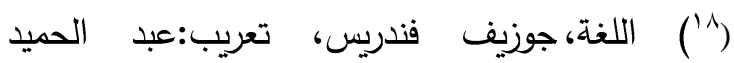

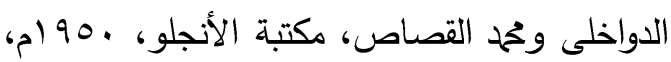


ولظظه معناه، فلا يكون لُظه إلى سمعك أسبق من من معناه في قلبك.)("r) فكأني بالجلخظ يلزم البليغ بالتوازن بين اللظ والمعنى، فيمن اختيار

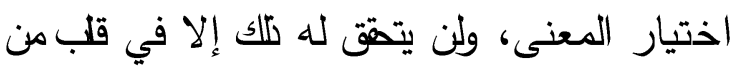
من اللظظ بليغ، والجلظ دقيق في كلامه، فهو يظطب

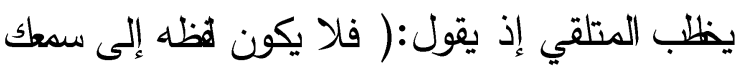

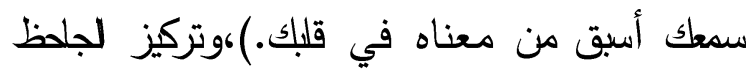

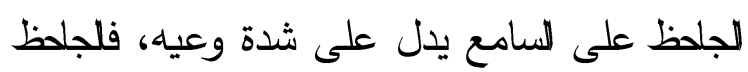
فلجلطظ من زعماء المعتزلة النين امتلكوا أزمة أزمة الخطاب زمنا، وكان كل هدفهم إحداث التأثير في السامعين؛ لناك وضع الجلة وكان المتلقي

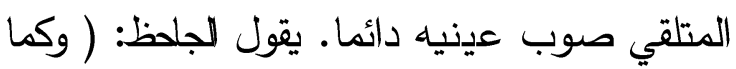

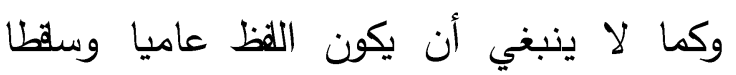
وسوقيا، فكلاك لا ينبغي أن يكون غريبا وحشيا، وحشيا، إلا أن يكون المتكلم بدويا أعرابيا، فإن لان لانيا،

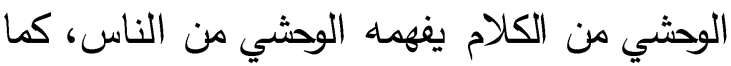

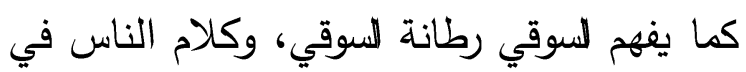

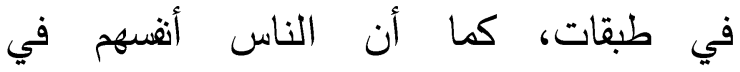

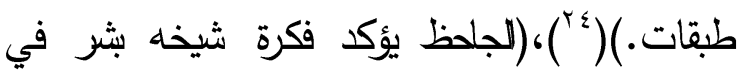

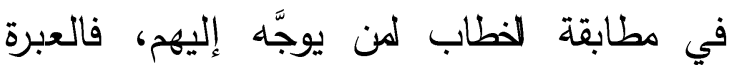

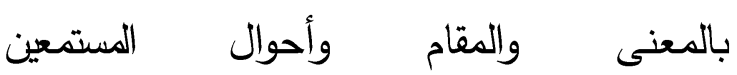
النفسية.)( (1) .إن من يريد النجاح لحقيقي في

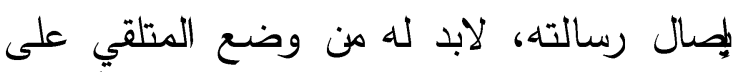
رأس اهتماماته. فقد كان أبو علقة رجلان نحويا واشتهر عنه شدة تقعره في الكلام، فكان يستخدم يستخدم غريب اللظظمن اللغة في التعبير عما يريد،

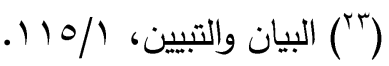

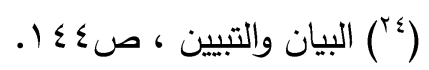

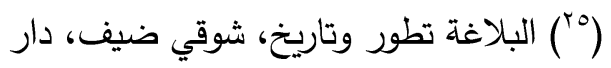

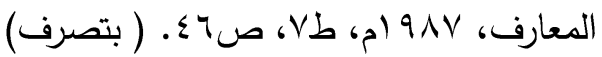

بالإيجاز البلاغي قدر الإمكان بعيدا عن عيوب

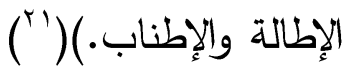
إن العسكي والرزي ركزا على أهمية تككن المعنى

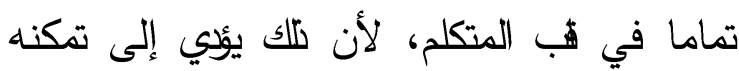
كنلك في هب السامع والمتلقي، فكأني بهما يقولان:

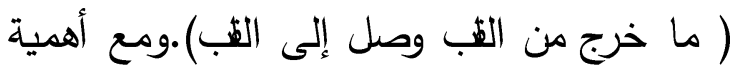
تكن المعنى في هب المتكلم لابد من هن اختيار الألفلظ، وإتقان صياغة العبارات، مع مراعاة

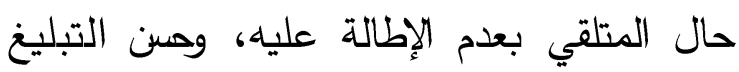
لايه.

وفي علم الأسلوبية الحيث نجدهم يتحثن عن مراعاة حال المتلقي تت عنوان: الأنس لأسلوبية

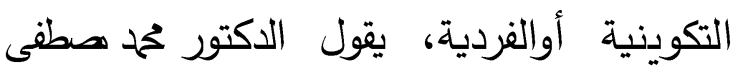
هدارة: ( ومن أهم الباحثين في هذا الاثجاه "سبيتزر" وقد وضع مجموعة من القواعد التي هي لهين يهني بها البلث الأسلوبي، منها:

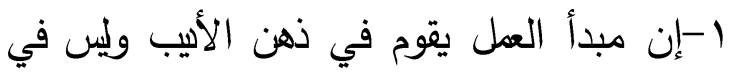
لظروف المادية المحطة به. ץ-إن اللغة انعكاس شفصية الأسب، وتبقى غير

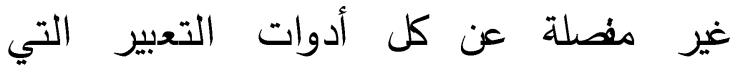
يمتلكها.(T) ثانيا: من علماء البلاغة من ركّز على جانب المخاطَب ( المتلقي ) بوصفه لطرف الثاني في

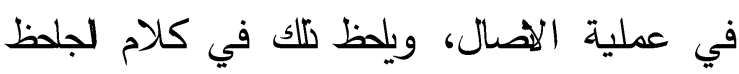

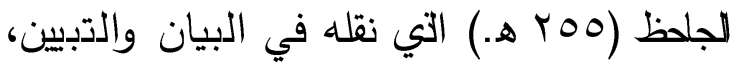

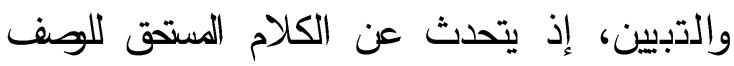
للوفف بالبلاغة فيقول: (لا يكون الكلام يتحق لإنق يستحق اسم البلاغة حتى يسلق معناه ثظه، وفظه

(") السياق في الدراسات البلاغية والأصولية ، صك.

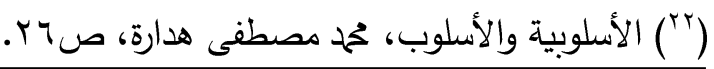


استعراض عضلات لبطل كمال أجسام أمام هزيل هزيل نحيل، فأضحى موقفه كالمرآة فيكف الأثل!!

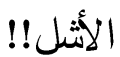

والقرآن الكريم نزل على الرسول الأمين يظلب

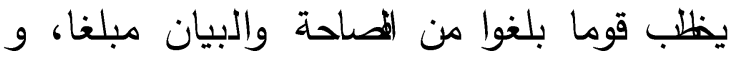
و بالرغم من نلك كان يفهمه كل من يقرأ آياته، ولم ينقل عن أحد منهم أنه عانى من فهم خطاب خطاب القرآن الكريم. وتعددت الآيات في القرآن القرآن الكريم التي ض على وضوحه وبعده عن

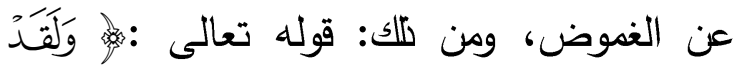

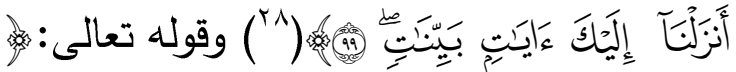

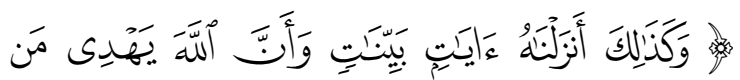

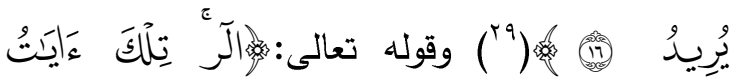

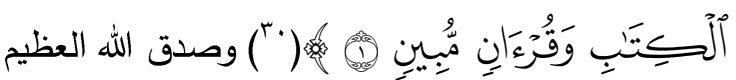

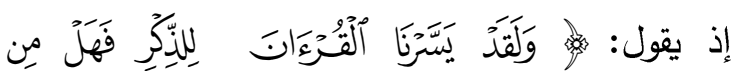

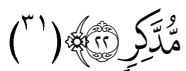

ثالثا: من الجوانب التي راعتها تعريفات البلاغة؛ جانب المقام (السياق):

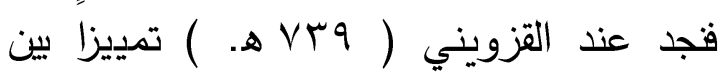
بلاغة الكلام وبلاغة المتكلم، ويحد كلا منهما على حده، فيعرف بلاغة الكلام بقوله: ( هي ولي

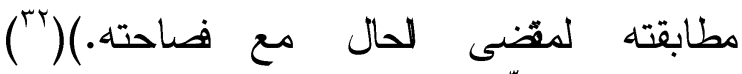

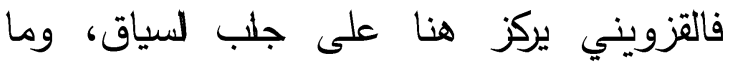

يريد، وكان يفتي في الين بغربب الألفظ، ويتشدد

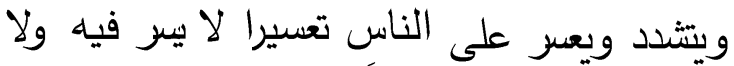
ولا لين. فحَثث أنه (خل على الطيبي فقال : إني إني أكت من لحوم هذه لجوزال، فلسئت طسأة،

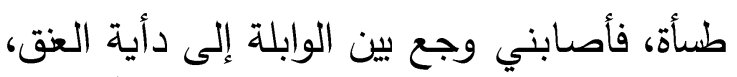

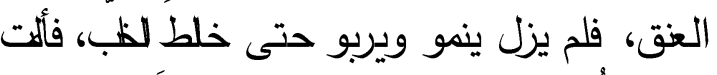

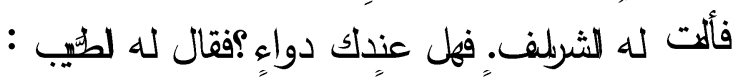
الطيب : خذ خربقا وشلفقا وشبرقا فزهزقه وزقزقه وزقزقه واغسله بماء روث واشربيه بماء

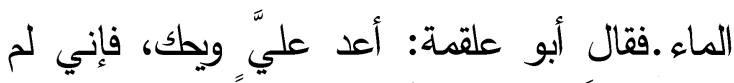

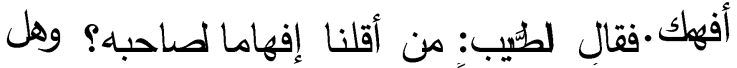

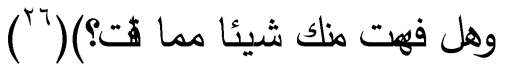
إن عدم مراعاة المتكلم لأحوال المتلقين بإغرابه

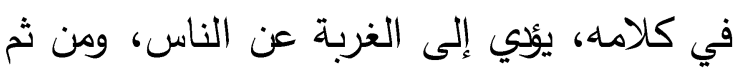
تكون العزلة التي فرضها أبو العلاء المعي على على نفسه. يقول الدكتور شوقي ضف عن المعي:( وربما وربما كان لضيقه بالحياة وبرمه بها أثز في هذا

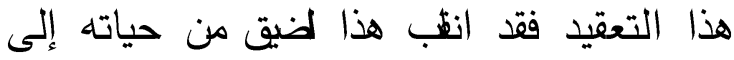
فنها، فإذا هو يعقده على الناس حتى يفس

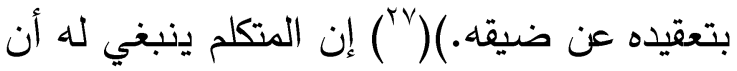

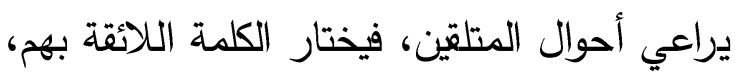
بهم، بمب ثقافتهم ووظائفهم. فمن تعد لصعوبة العية

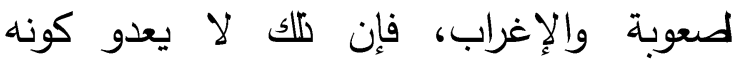

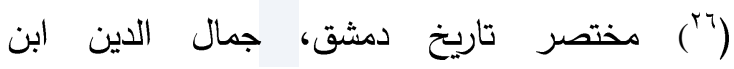

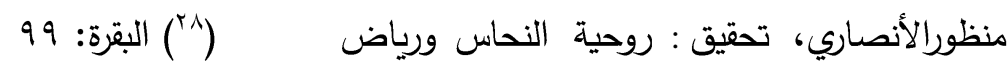

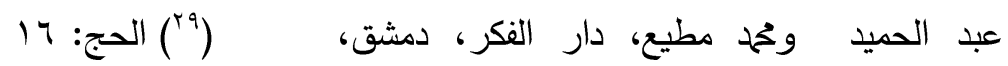

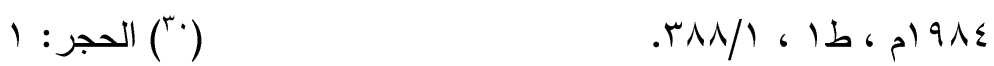

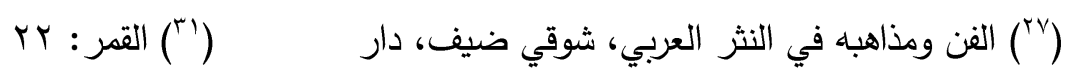

المعارف، ، .911، ط96، ص997. 
ولمفهوم لسياق تعريف عند السجماسي ذكره عند عند حديثه عن الإيجاز بالحذف، فهو ( ربط القول

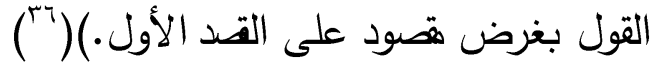
(فلاياق هو القاعدة الداخلية التي ينحرف عنها الأسلوب، إذ تتحدد أي ظاهرة أسلوبية بكونها

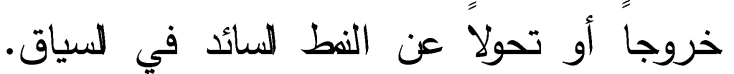

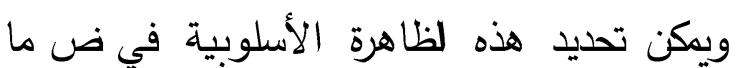

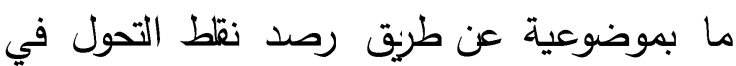

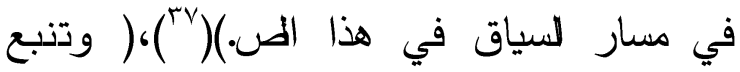

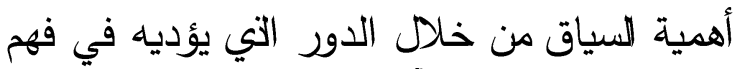
فهم المعنى، تلك أن الكلمة تكتب مدلولها من لن لهن السياق، وتتغير هذه الدلالة بتغيره، وإن كان هذا

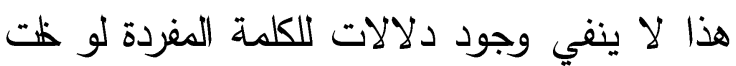

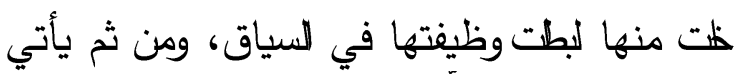

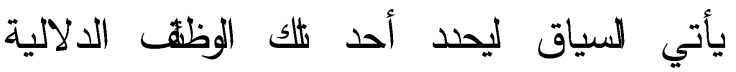
$\left({ }^{r \wedge}\right)($ للكلمة وقد تناول علماء اللغة والبلاغة للسياق وأثره

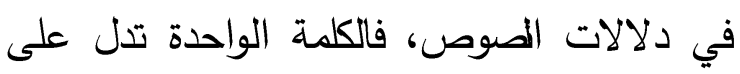
معاني متعددة، تدنوع وتتعدد هب لسياق التي وضعت فيه . كئ.

ففي كتاب (علم الدلالة) للاكتور أحمد مختار

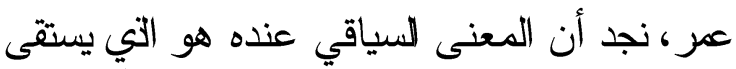

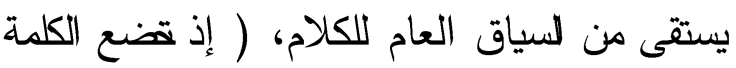

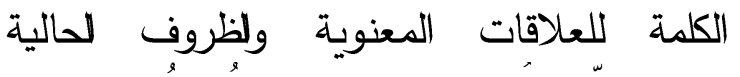
والتعبيرية المميطة بها، التي يألف بضها مع بضرِ

("7") المنزع البديع في تجنيس أساليب البديع، القاسم بن

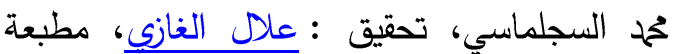

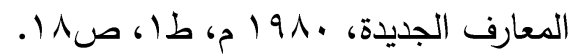

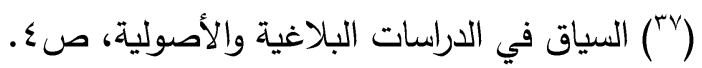

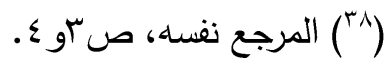

يتواءم معها من ألفظظ مناسبة تصضي وصول الرسالة تامة في جلب من الفلحة بائن.

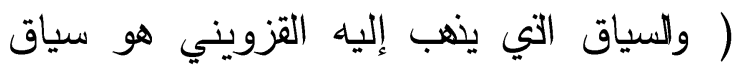
الموق، وهو استخدام خاص لالالة السياق عند البلاغيين حين التمييز يين سياق الص، وسياق

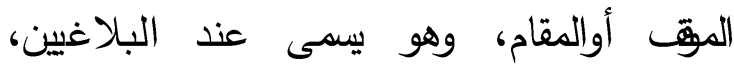

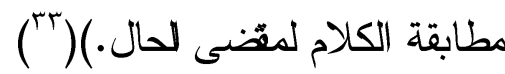
ويوى الاكتور محمدطفى هدارة أن السياق يتأثز يتأثز بتغير الأحداث المحيطة بالأسب، ( فلثعراء

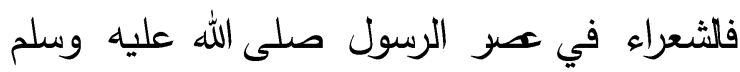
وسلم يتوجهون بمليحهم إليه، ونلمظ في مدئحهم

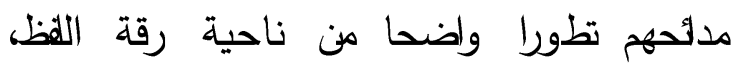
والاهتمام الرئيسي بالفكرة دون بهرجة الكلام

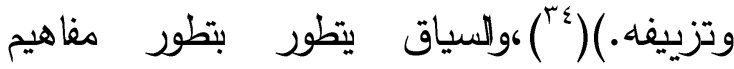

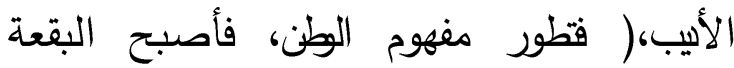
لجديدة التي يیش فيها الإنسان، فاختفى في القرن

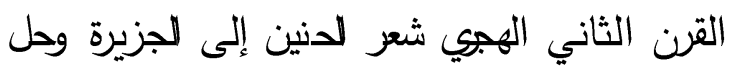

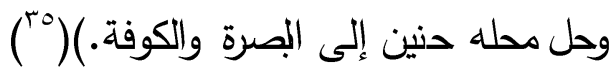

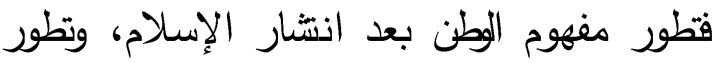

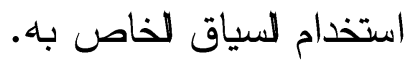

(") السياق في الدراسات البلاغية والأصولية، صبّ.

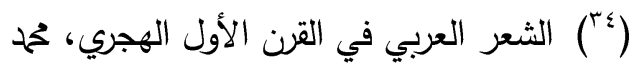

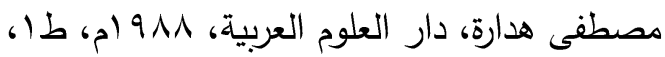
ص.1.

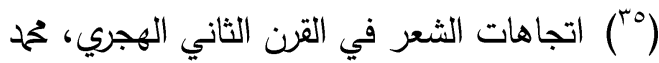

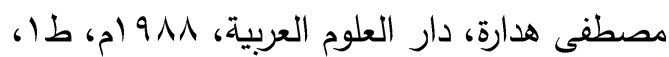


بل هو مسوق معها سوقا، ليؤدي مجموع المعاني

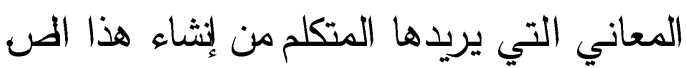

الص

وقد تحدث الدكتور أسامة عبد العزيز جابالله عن عن السياق قائلا:( السياق هو الصورة الكلّية التي تتظم بداخلها الصور الجزئيةً ، ولا يفهم كل جزء إلا في موقعه من الكل، فالصورة الكلّية تتكون من مجموعة كبيرة من النقاط الصغيرة

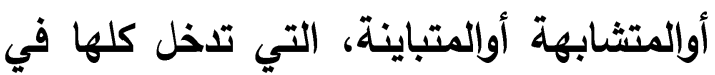

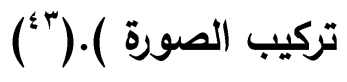

إن التعريف السلق تناول مفهوم السياق بطريقة شمولية، فلصورة الكلية وتتبعها لهورة لجزئية توجد في القرآن الكريم، ونلمظها في شعر الشعراء وبلاغة الأدباء، بل ونراها كللك في عبارات

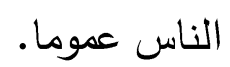

\section{( ) المفسروز والسياق :}

علم لالسياق القرآني علم عظيم المنزلة رفيع القدر، وهو من أهم ما يوصل للفهم لهحيح لكتاب لكتاب الله تعالى؛ إذ هو لطريق الأسلم لجعل كلامالله كلامالله متناسبا منتظما، وهذا هو الأبب لكتاب الله

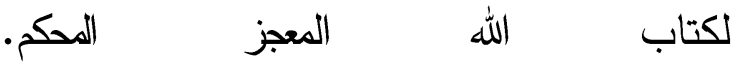
وإن من أعظم ما يبين منزلة هذا العلم أنه مرتبط مرتبط حقيقة بالقرآن نفسه من هيث إنه ثقير للقرآن بالقرآن، لتلك أنه تفير للآية بما تضمنه نصها، أو بما سبقها ولحقها من الآيات، وهذا من بن من ثقسير القرآن بالقرآن، بلى هو أقىى مرلت هذا هذا النوع، وتلك أن تقيير القرآن بالقرآن قد يكون يكون في محل واحد وسدورة واحدة، وقد يفترقان،
بض لتبين المعنى لخاص لثلك الكلمة، التي سمي

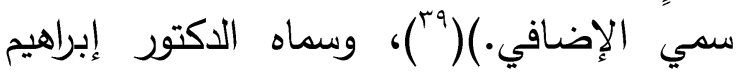
أني:(الهلمشي)، وعبر عنه تارة أخى فقال: (هو الإه

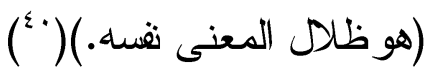
فللكلمة معنيان: معجمي وسياقي.( والفارق الأساسي بين المعنيين؛ المعجمي والسياقي، هو

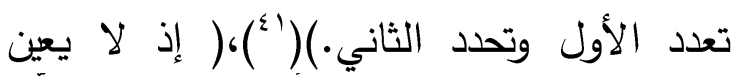
الأول على تحديد البعد الدلالي للكلمة؛ لأنها تحتل أكثر من معنى، وهو في الغلب معنى منفرد مغلى يقوم على التجريد، أما الثاني فهو فهو معنى محدد تحكمه علاقة الكلمة بكل ما يحيط

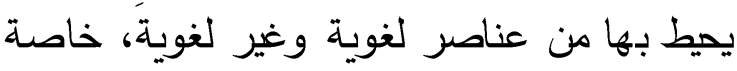
خاصة بالمتكلم والمثلب، ثقافية واجتماعية، ولذا ولذا فهو لا يقبلٍ التعدُّد، ففي كل سياق تكتب الكلمة معنى محددا مؤقتا يمثل القيمة للضورية المضورية لها، التي تختف من سياقٍ إلى آخر •)

\section{ويتضح للباحث من حلديث العلماء المعاصرين :} أن المعاني لاسياقية للكلمة الواحدة تتعدد بتعدد لإياقات التي ترد فيها. وما تعنى به هذه الاراسة: هو تناول مفهوم السياق وقيمته في الدلالة؛ لأن الص في كلام المتكلم لا يوجد منفردا عن بقية أجزاء الكلام، بل

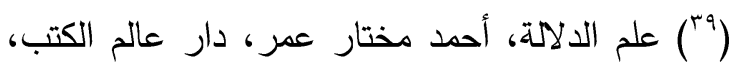

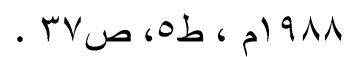

(•) دلالة الألفاظ، إبراهيم أنيس، مكتبة الأنجلو

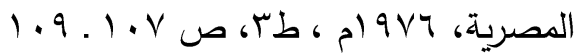

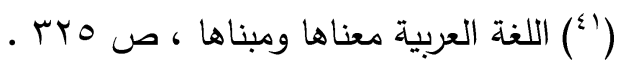

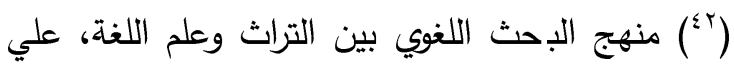

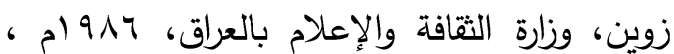


السياق في انتقاء الدلالة الراجحة للص. والثاني: والثاني: دور السياق في عملية ترجيح الأقوال

وهما معاً يوضحان أهمية السياق ومنزلته في لاتيا.

$$
\text { الدراسات التصييرية.)( }
$$

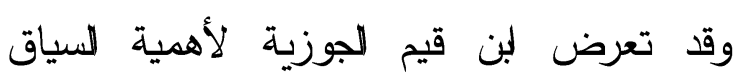
ودوره في فهم تفير القرآن الكريم في كتابه

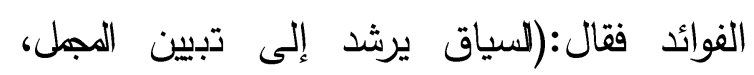
وتعيين المحتل، وإقطع بعدم احتمال غير المراد،

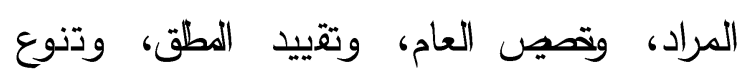

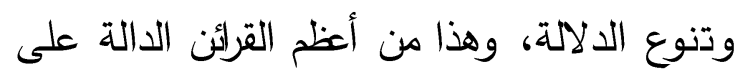

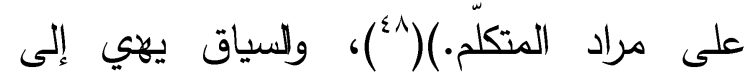

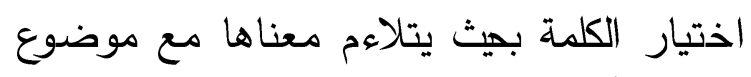
الص،( إن" السياق هاد إلى اختيار المعنى المراد

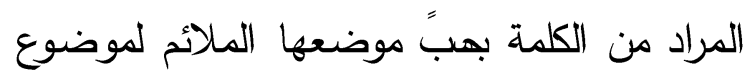

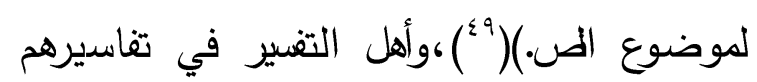

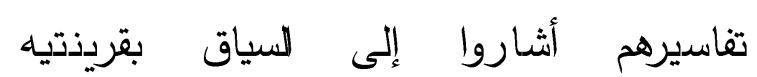
المتلازمتين؛ اللظية والحالية، فن القرآن ما ورد ورد ثعسيره بالنقل عمن يعتد بتعسيره، ومنه ما لم

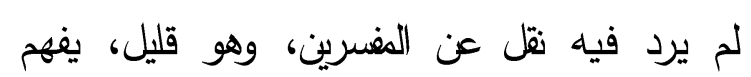
بالظر إلى مفردات الألفظ من لغات العنبر وهرب

$$
\text { ومدلولاتها واستعمالها بهب السياق. }
$$

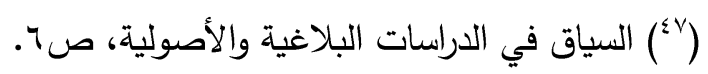

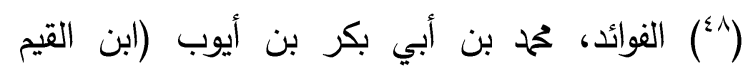

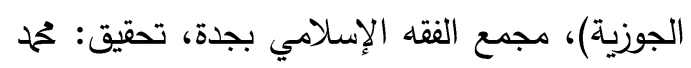

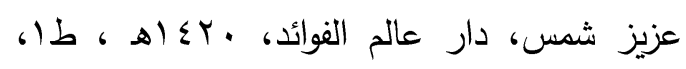
. $\mathrm{N} r /$

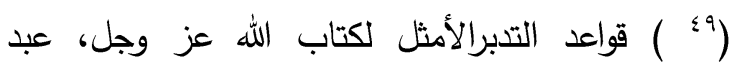
الرحمن حبنكة الميداني، دار القلم، دمثق، .
يفترقان، وأقتى النوعين وأسلمهما ما كان في مطل مل واحد وسدورة واحدة ، وهذا هو السياق.

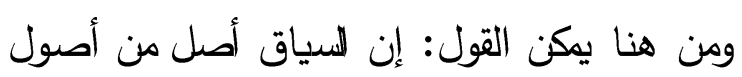

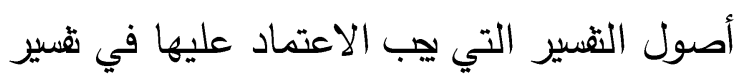
تُسير كتاب الله تعالى.قال لبن تيمية: (ينظر في لئل كل آية وحسث بهوصه وسياقه، وما يبين معناه

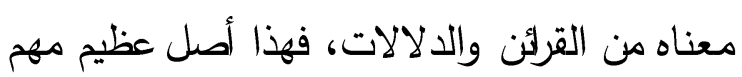

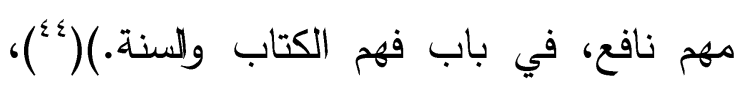
وقال البن دقق العيد: (أما السياق والقرئن، فإنها

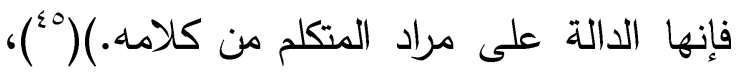

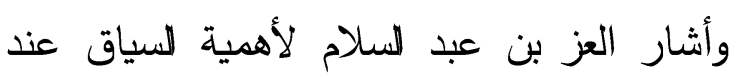

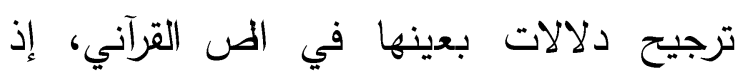

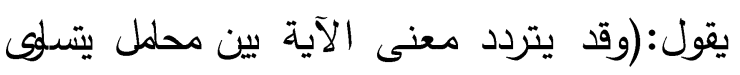

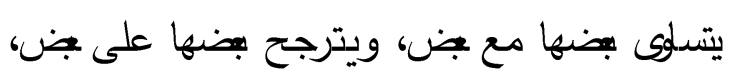

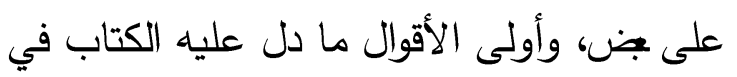
في موضع آخر أو السنة، أو إجماع الأمة، أو الو لئال

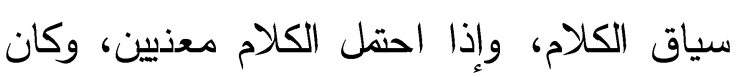

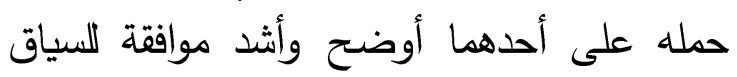

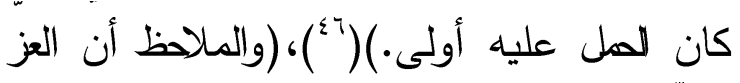

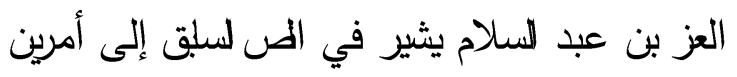
أمرين غاية في الأهمية هما: الأول: دور السياق لفئ الفى المين

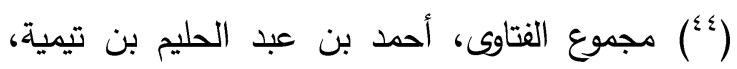

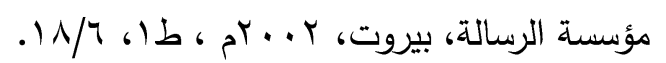

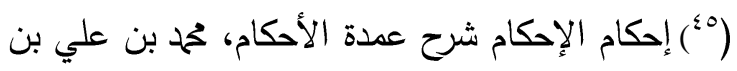
وهب الشهيرب ( ابن دقيق العيد المصري)، تحقيق:

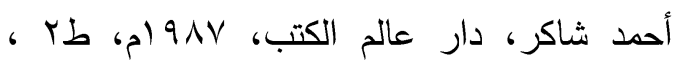
. $T$ T $\leqslant / T$ (T7 الإشارة إلى الإيجاز في بعض أنواع المجاز ، عبد

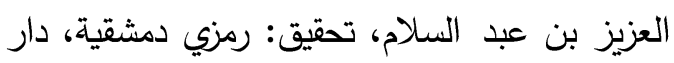

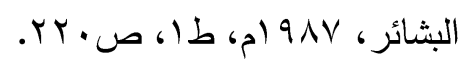


اللغوي.)(") ،وأكثر ما تظهر أهمية السياق عندما عندما يلتس المعنى، فالسياق هو التي يزيل الإبهام الإبهام عن المجل، ويوضح تصيس العام أو تقييد

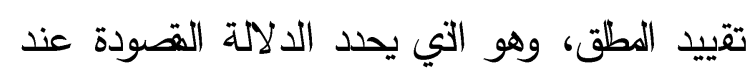
عند تنوع دلالات اللظط، فإنه من أعظم القرائن الدالة على مراد المتكلم. ففي قولالله تعالى:

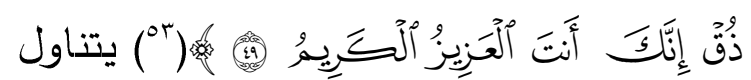
لطاهر بن عاشور هذا لسياق القرآني التهكي

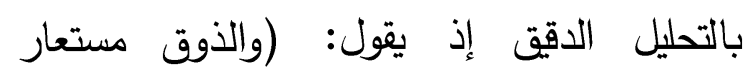

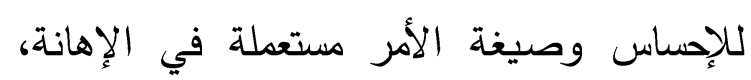

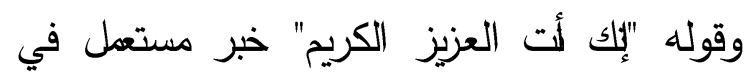
في التهكم بعلاقة لضدية، والضصود عكس مدلوله،

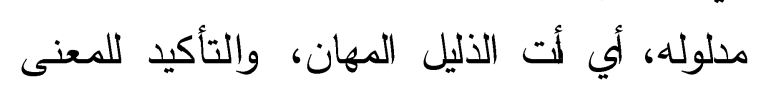

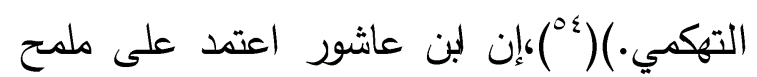

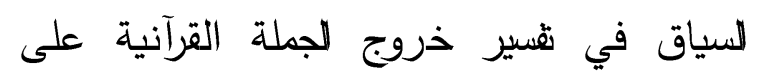

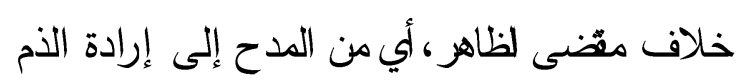

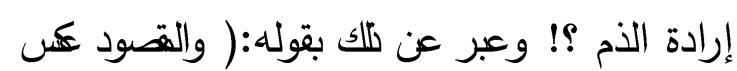

$$
\text { عس مدلوله). }
$$

وبعد التأصيل السلق عند علماء ثُسير القرآن

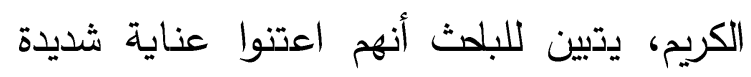

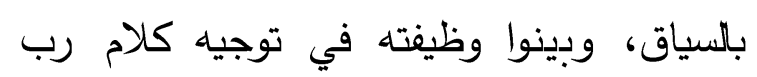

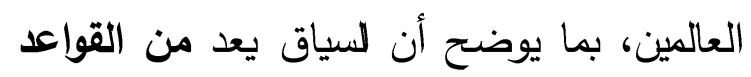

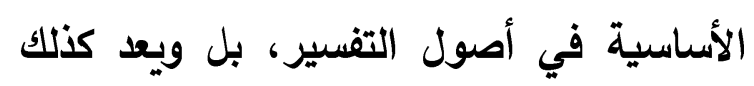
إحدى قواعد الترجيح المعتبرة.

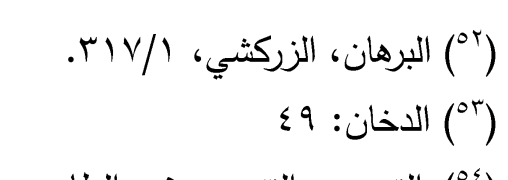

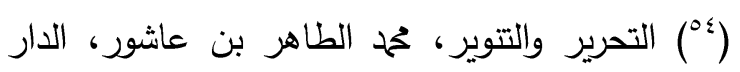

وقد اعتنى بهذا الرافب الأصفهاني في كتابه

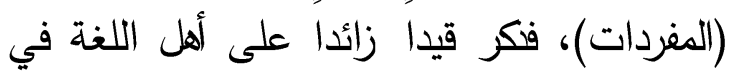
تفير مدلول اللظ وهو ( الإثدارة إلى المناسبات

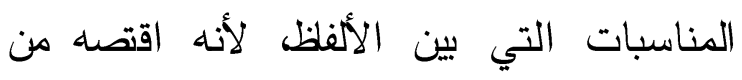

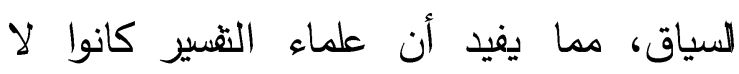

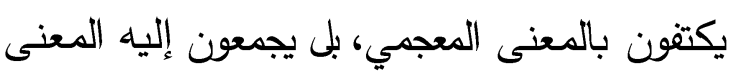
المعنى السياقي..)(

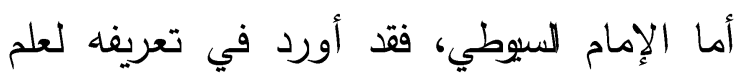
النتسير ما يدل على إدراكه الواعي لقيمة السياق

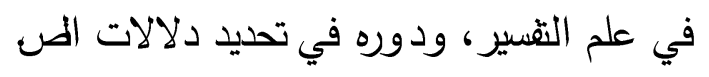

يقول السيوطي:( التُسير كف معاني القرآن، وبيان المراد منه، سواء أكلت معاني لغوية أو لفوطي

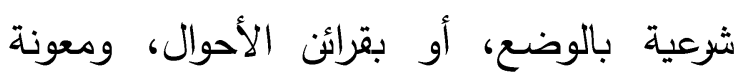

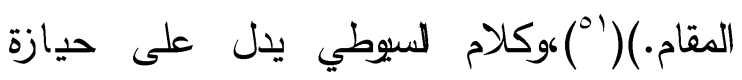
السياق لأهمية كيّى عند الدفرين في تناولهم لسياق الآيات، وتحديد دلالتها، ومن ثم الاهتداء إلى التقيير المنلب لها. وقد أكد الزركثي أكثر من مرة على أهمية مراعاة

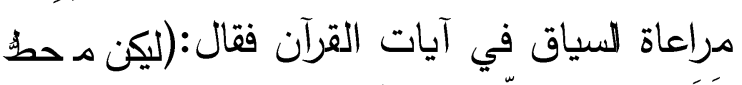
هـ حطظر الففر مراعاة نظم الكلام التي سيق له،

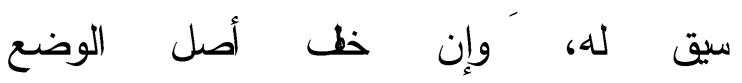

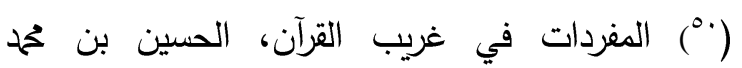

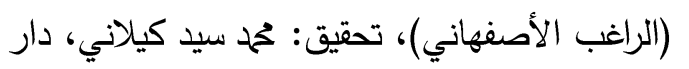

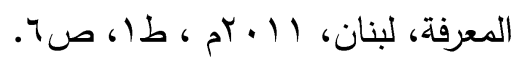

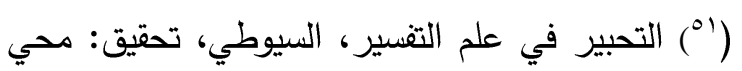

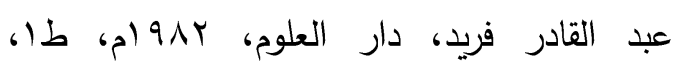


بمثيلتها التي ثبت فيها ل لحرف المحذوف، فالكلمتان هما هما والرسم مخدة، والسبب هو السياق التي وردت فيه الكلمة، كما سيضتح تلك تلك في فهول البث التالية.

\section{(0) السياق عند الأصوليين :}

إن عناية الأصوليين بمبث لسياق كتت متميزة متميزة عن المفسرين والبلاغيين، إذ نجدهم يستندون إليه في تحديد الكثير من دلالات الألفظ؛ الألفظ؛ لا سيما في الص القرآني، فلسياق يزيل يزيل الإبهام عن المجل، وضضص العام، ويقيد ويقيد المطقَ، وهو من لُغم القرئن الدالة على على مراد المتكلم. يقول لبن دقيق العيد: (أما

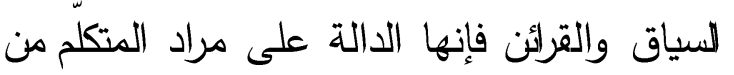
من كلامه.)("^)، (وقد تناول الأصوليون بثكل واضتح السياق اللظي والاجتماعي، هُلوا القول القول في عناصره، وأثز ذلك في تحديد المعنى، المعنى، وفاقوا بدراستهم لله البلاغيين، وتميزوا من المفسين بجولب كثيرة من البث في للسياق، السياق، وإن اشترك كلاهما في دراسة الصوص مل

$$
\text { الصوص الشرعية.)( }
$$

قال السرخسي: ( القرينة التي تقترن باللظظ من المتكلم، وتكون فرقا فيما بين الص ولظاهر هي هي لالسياق، بمعنى الغرض التي سيق لأجله

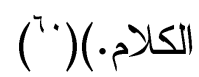

(0)

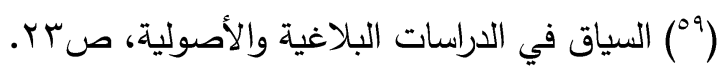
(") أصول السرخسي، ححم بن أحمد بن أبي سهل

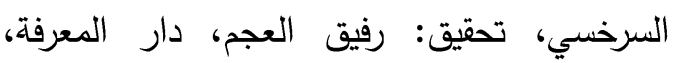

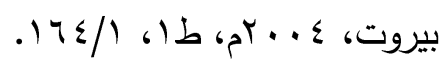

يقول الدكتور أسامة عبد العزيز جابالله في بحثه بحثه (لسياق في الدراسات

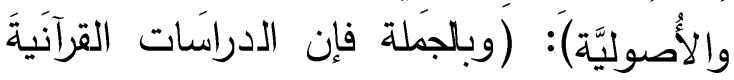
في جلب آلتّير اتقت فيما بينها على اعتبار وظيفة لسياق الترجيحية إحى قواعد الترجيح المعتبرة.)( $)$ ويقول الشيخحمد رشيد رضا:(إن فُلى قرينة تقوم قرينة تقوم على حقيقة معنى اللظ؛ موافقته لما

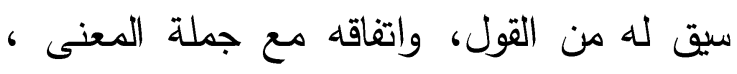
وائتلافه مع الهد الني جاء به الكتاب

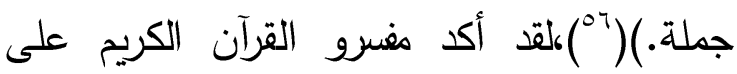
مدار الأزمان على أن الكلمة القرآنية لا يفهم معناها على الوجه لهحيح إلا في سياقها. وللقرآن الكريم خاصية لا تتوافر لغيره من الكب، الكب، وهي أن السياق يتجاوز الكلمة والجملة والعبارة، يتجاوز تلك كله، وربما كان سياق السورة كلها له أثره في فهم المراد، وربما كثت كثت لسور المجاورة لها أثرها كنلك، وصدق الله

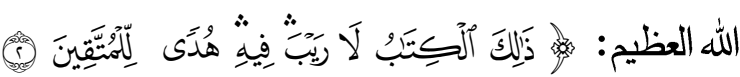

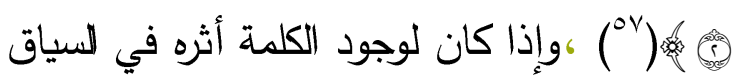
السياق القرآني، فإن لحذفها من لسياق عظيم الأثز. الأثز. وعندما تحذف بن الأحرف من الرسم القرآني، يكون لهذا لحذف دلالته البلاغية العميقة بالتأمل في للسياق، ومقارنة الكلمة

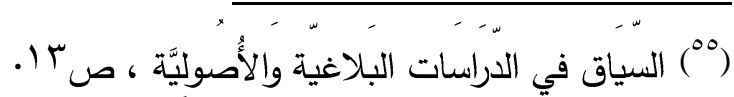

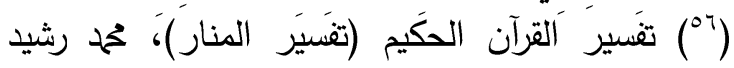

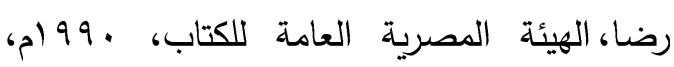
br/1 מ / r: البقرة 


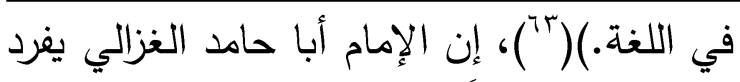

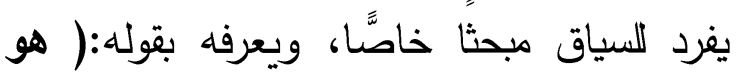
فهم غير المنطوق به من المنطوق بدلالة

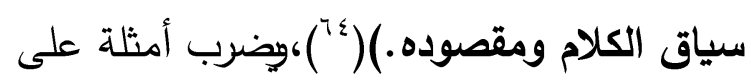

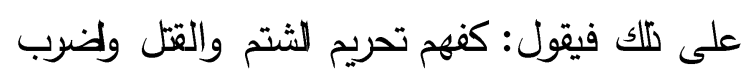
والضرب من قوله:

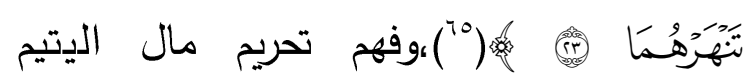

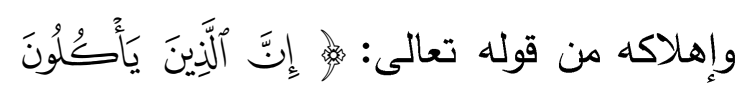

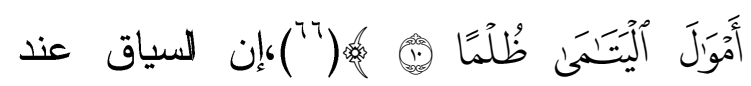
الإمام الغزالي يبين قصود الكلام ويعين المتلقي

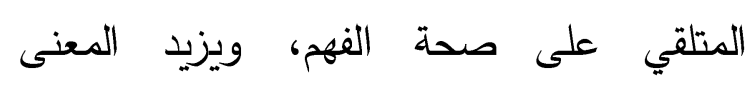
وضوحا، بهي لا يترك مجالا للالتباس على ولى

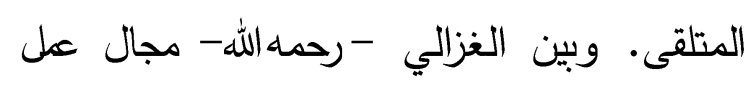

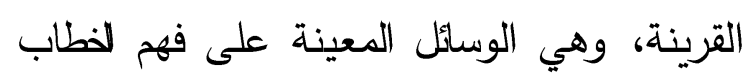

$$
\text { الخطاب الشرعي، فيقول: }
$$

( ويكون طريق فهم المراد تقدم المعرفة بوضع اللغة اللغة التي بها المخطبة، ثم إن كان نصا لا يحتمل يحتمل كفى معرفة اللغة، وإن تطرق إليه الاحتمال الاحتمال فلا يعرف المراد منه حقيقة إلا بلضمام

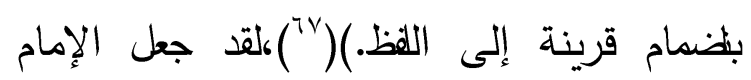
الغزالي الفهم هو الغرض الأساسي من لخطاب،

(") (") دراسة المعنى عند الأصوليين، طاهر سليمان

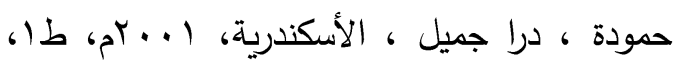

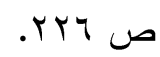
(") المستصفى من علم الأصول، أبو حامد الغزالي،

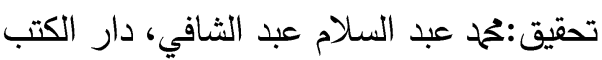

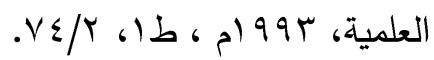
r r

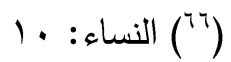

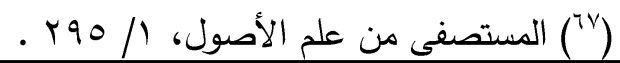

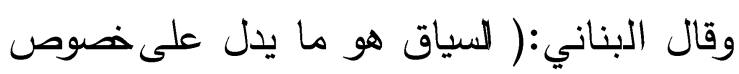

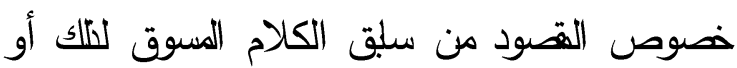

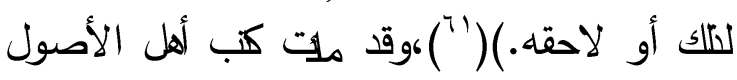

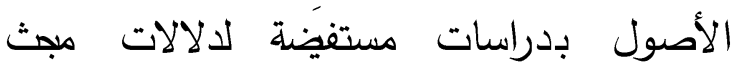
السياق، نجد نلك في دلالة الأمر وتصيص العام العام والحقيقة والمجاز والمشترك اللظي وتقييد

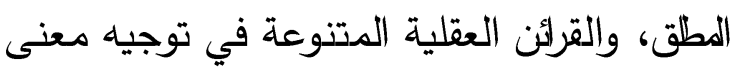

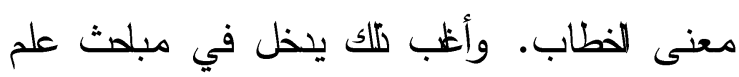
علم المعاني. وقد نبه الأصوليون على أن الألفظ المفردة والتراكيب تتعرض لأنواع من التغير الدلالي ببب الاصب الني

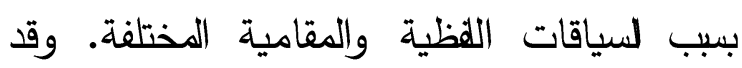
لضح لأك في تناولهم للظ العموم.(لأن العوم إنما إنما يعتبر بالاستعمال، ووجوه الاستعمال كثيرة، كثيرة، وكن ضلبطها مقضيات الأحوال التي هي الأنيال

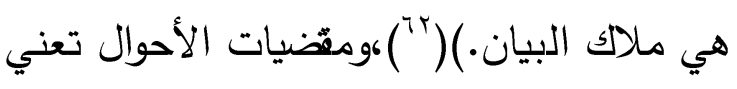
تعني استخدام لسياق المناسب لحالة التي عليها

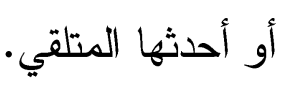
(وقد أدرك الأصوليون السياق بأنواعه، وتحدثوا

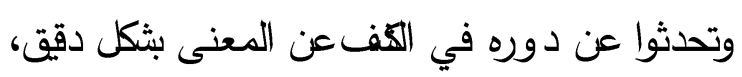
بثكل دقيق، وأدركوا أثز لظواهر الاجتماعية في

(") حاشية البناني على جمع الجوامع، عبد الرحمن بن جاد الله البناني، تحقيق: تحمح عبد القادر شاهين،

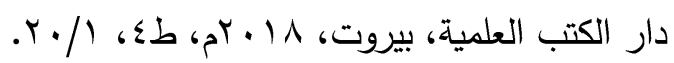

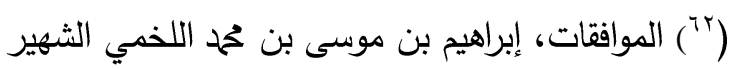
بالثاطبي، تحقيق:مشهور بن حسن آل سلمان،

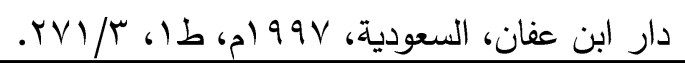


تعالى: " أو ما مهت أيمانكم " فالمراد كونه

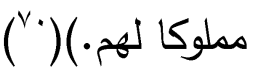

قال أبوحيان:( اليمين هنا والقضة عبارة عن القدرة، وما اختلج في للدرر من غير تلك فهو بلطل.)( (v) ،والعرب تقول هذه الدار في قبضة فلان على سبيل المجاز، يعني في قدرته وتت تصرفه.،وبمثل هذا قال أبو السعود في تعسيره: "

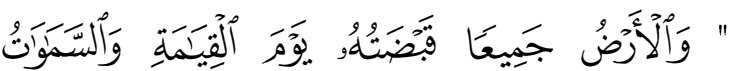

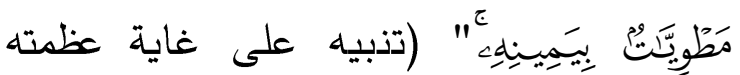
وكمال قدرته، وحقارة الأفعال العظام التي تتصير تتصير فيها الأوهام بالنسبة إلى قدرته تعالى. r - (وإما قرئن أحوال من إثارات ورموز وحركات وسولق ولولحق لا تخل تت لهر لهر والتخمين يت بدركها المشاهد لها فينقلها فينقلها المشاهدون من لهحابة إلى التابعين بألفظ

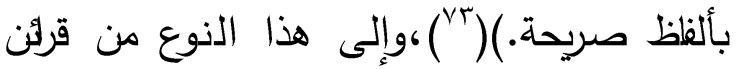
السياق أشار لجلحظ في البيان والتبيين في باب البيان بقوله:(جميع أصناف الدلالات على المعاني من لظظ وغير لّظ خمسة أشياء لا تهّ ولا

(") البحر المحيط في التفسير، أبو حيان ححم بن يوسف بن حيان الأندلسي، تحقيق: صدقي حمح

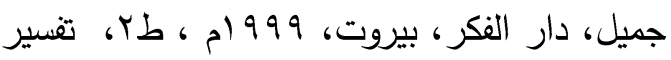

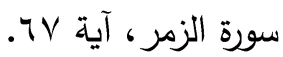

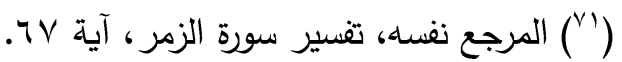

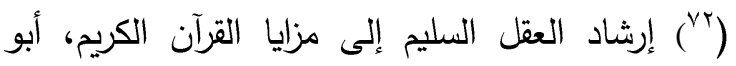
السعود محم بن ححم العمادي، دار إحياء التراث

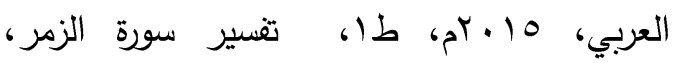
. TTY/E

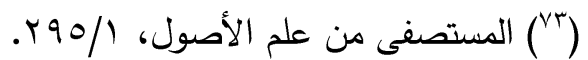

للطاب، فإن كان نصَّا واضحا لا يحتل التأويل التأويل كفى بمعرفة اللغة في فهمه، وإن كان نصا نصا يحتمل التأويل فإن بيانه يعتمد على السياق بقرائنه. والقرينة التي ترتبط بفهم السياق عند الإمام الغزالي على ثلاثة أضرب هي: 1 - إما لظظ مكثوف كقوله تعالى :

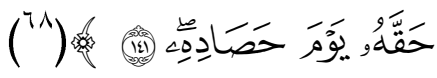
r

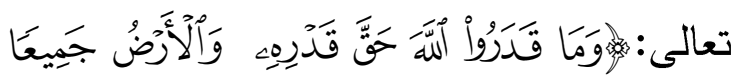

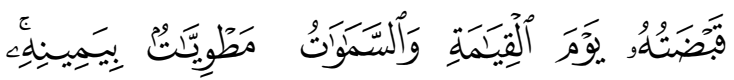

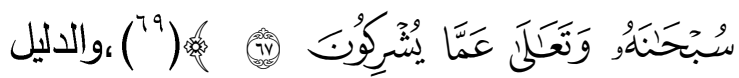
العقلي التي تيده الإمام الغزالي في قوله

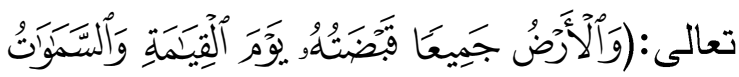

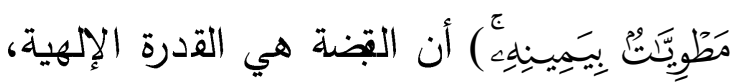
وبهذا قال علماؤنا. قال أبو حيان : ( والغرض من هذا الكلام إذا أخذته كما هو بجملته ومجموعه، ومجموعه، هو تصوير عظمته والتوقيف على كنه كنه جلاله لا غير، من غير ذهاب بالقضة ولا باليمين إلى جهة حقيقية أوجهة مجاز. فلظ القضة واليمين حقيقة في لجارحة، والاليل العقلي قائم على امتناع ثبوت الجوارح والأعضاء والأعضاء لله تعالى، فوب الحمل على المجاز أله المجاز، وتلك أنه يقال فلان في قضة فلان، أي أي إنه تهت تدبيره وتخيره، ومنه قوله تعالى: " أو 
تَِّيمُ

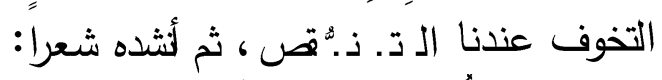
تخوَّف الرَّحل منها تامكًا قَردًا

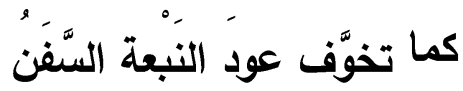

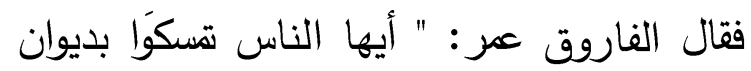

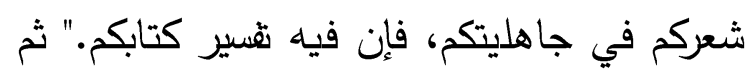

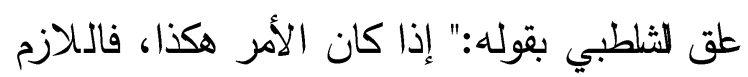

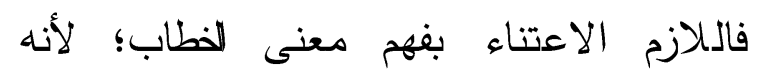

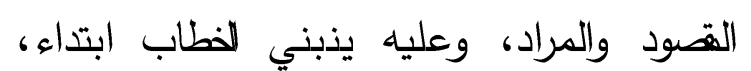

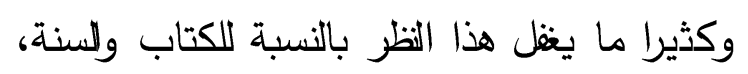
والسنة، فتلفس غرائبه ومعانيه على غير الوجه الوجه التي ينبغي، فتستبهم على الملتس، وتستعجم وتستعجم على من لم يفهم مقاصد العرب، فيكون فئن

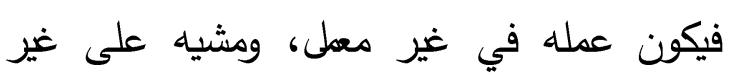
طريق،والله الواقي برحمته." )( إن كلام الإمام الثلطبي يفيد أن السياق يزيل بلهيل

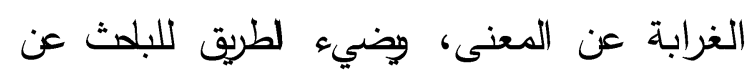
الحق، فيهني إلى المراد من الكلام.

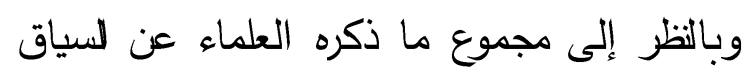
السياق ودوره في فهم نصوص الكتاب المبين، يمكن القول: إن السياق مؤلف من ثناثة فئل

عناصر :

أولها: الغرض : والقصود ومراد المتكلم.

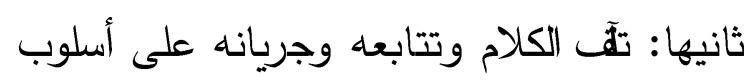
واحد. أسلوب ثالثها: لظروف المحيطة بالظ، وأحوال المخطسين الهخطيين فيه .واستيعاب للياق لهذه العناصر

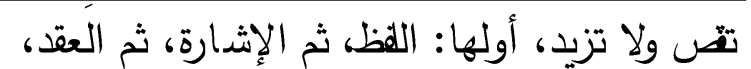

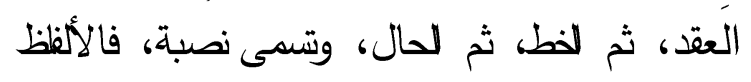

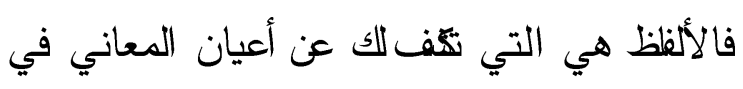

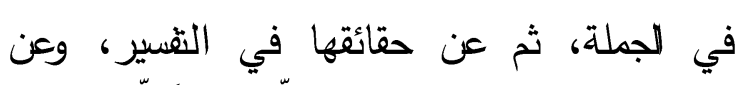

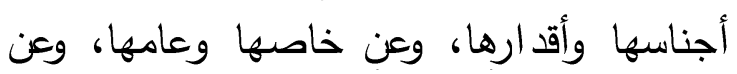

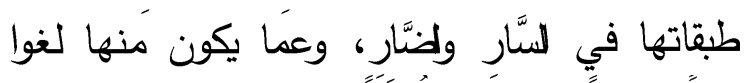

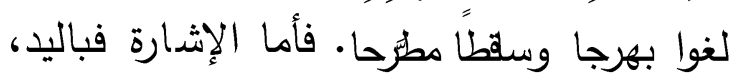

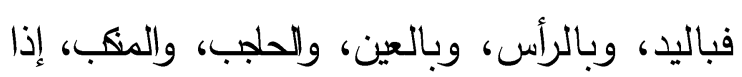

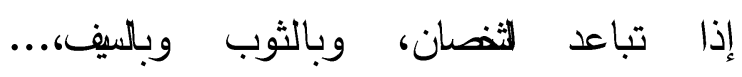
والإثدارة واللظ شريكان، ونعم العون هي له،

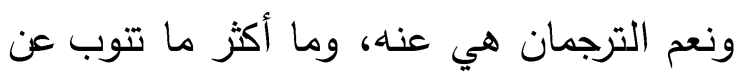

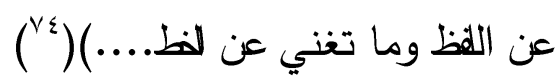

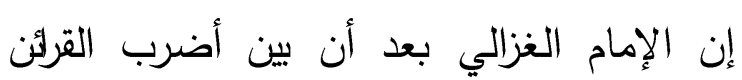
الثلاثة، بين إمكانية تمازجها، فقال: (أومع قرئن

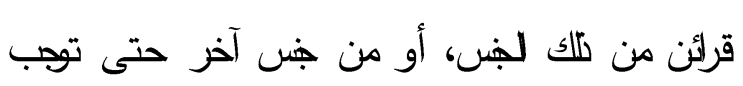

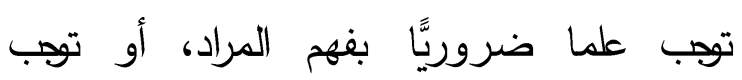
ظنا.)( وبين الغزالي ضرورة القرائن في فهم للسياق

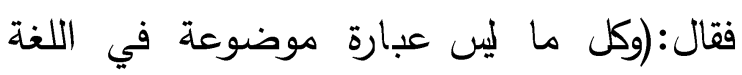

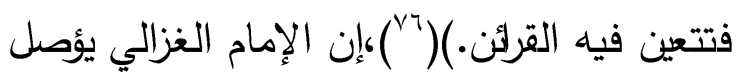
يؤصل لمسألة القرينة التي تنلب لسياق وأنواعها وأذواعها لما لها من أهمية في فهم الخطاب.

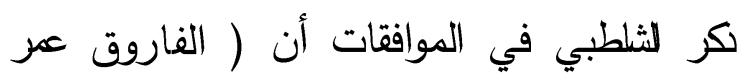
رضي الله عنه سأل عن معنى التخوف في قوله

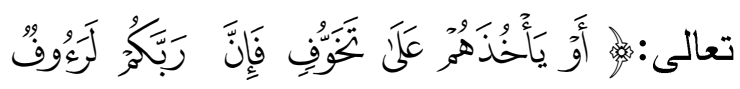


( وتقع ضمنهما الأذواع الأخىى، منها: للياق

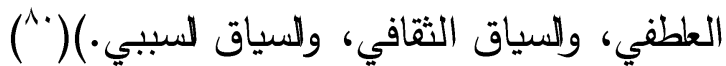

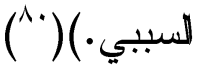

1 - السياق اللغوي ( اللفظي النصي ): وتصد به:النظم الفظي للكلمة، وموقعها منه. ويشمل الكلمات ولجمل لحقيقية لسابقة واللاحقة للكلمة، والص التي توجد فيه. فهو السياق التي توجد فيه اللظة في لجملة، فتكتب من لسياق توجيها دلاليا، وقد تأتي في سياق آخر فتكتب دلالة أخرى. ومثال تلك قولنا:(أعط السائل شيئا ) وقولنا: (الدواء السائل أسلم للأطفال).

(فهي الروابط اللغوية المحيطة باللظة في عبارة أو

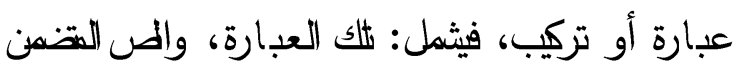
الهضمن لها، والكتاب الوارد فيه الص، وكل ما ما يصلب الفظة من ألفلظ تساعد على توضيح توضيح المعنى، تقدت عليها أو تأخرت عنها، عنها، مما يؤثز فوق الدلالة المعجمية، لي: أصل أصل الاستعمال اللزوي، مضيفا إليها الدلالة الثانوية التي تتغير بتغير الصر أو الثقافة أو طبيعة الأسان أو تصدوراته.)('^)،والسياق اللغي لهي اللغوي هو الإطار الداخلي للغة، وتصد باه ( الص الص التي تككر فيه الكلمة، وما يثتقل عليه من

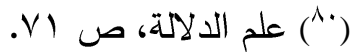

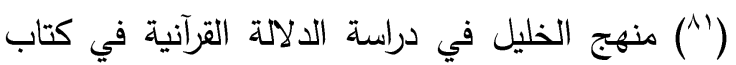
(العين)، أحمد نصيف الجنابي، المجمع العلمي

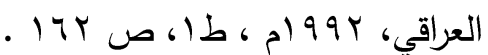

واشتماله عليها هو التي يوفق بين المعاني المختلفة

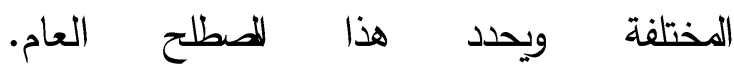
بناء على ما سبق يمكن للباحث تعريف السياق فيقول:(السياق هو الغرض الأي لأجله سيق الكلام، وهو الأي ينتظم به جميع مايرتبط بالنص من القرائن اللفظية والحالية.) وبهذا التعريف يتوقت المعنى اللغي والمعنى الاصطلاحي، ولذا فإنه يمكن أن يطق على غضر غضر دن عناصر السياق بأنه السياق باعتبار أنه أنه جزء منهه، وعليه يحمل إطلاق بض المفسرين المفسرين السياق، وغلب إطلاقهم السياق قصود بـ هضود به الغرض التي ورد الكلام لأجله.(وهنا لأجله. (وهنا يمكن تلذي القول في مفهوم السياق السياق في التراث العربي في النقاط الثلاث التالية:الأولى: أن السياق هو الغرض، أي قصود قصود المتكلم في إيراد الكلام .والثانية: أن لسياق السياق هو لظروف والموتف والأحداث التي ورد ورد فيها الص أو نزل أو قيل بثأنها .والثالثة: أن ولن ولئ أن السياق هو ما يعرف الآن بلسياق اللغوي التي التي يمثله الكلام في موضع النظر والتحليل، ويشمل ما يسبق أو يلحق به من كلام.)( ( 7 ) أقسـام السيـاق إن القرئن المساعدة في فهم المعنى إما لفظية وإما مقامية. وعليه فإن السياق قسمين رئيسين هما:لسياق اللظي(الصي)والسياق المقامي (لحالي

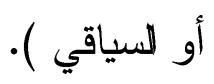

( ) (لالة السياق، ردة الله بن ردة بن ضيف الله

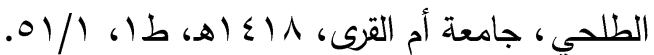


والتذكير والتأنيث، والتعريف والتتكير .)( (^) ،وهذه

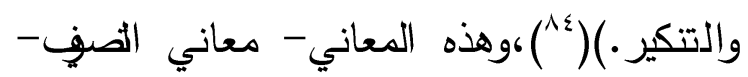

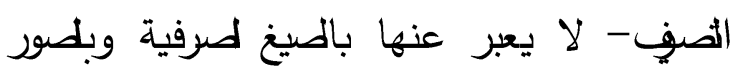
وبلصور الثكلية المختلفة، وهن يعبر عنها بولسطة

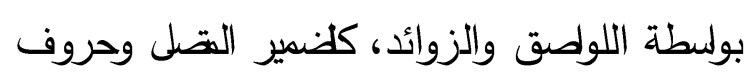
وحروف للضارعة وتاء التأيث والئ واللام للتعريف.

ثم يقسم الاكتور تمام القرائن الأخرى إلى : حالية ، ومقالية. (والمقالية شمل نوعين من القرئن هما: المعنوية، المعنوية، واللظية. والمعنوية هي: الإسناد والتصيص والنسبة والتبعية والمخالفة. واللفظية

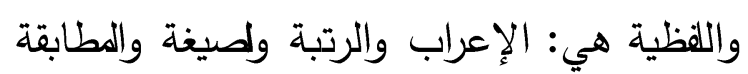

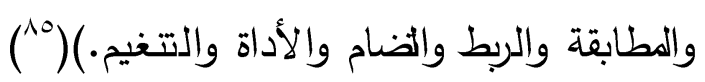

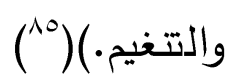
الضام:تضام الثيء، لضم بضه إلى بض، ويقال: تضام القوم وغيرهم. و كل هذه القرئن عوامل مساعدة، ولا يعرف إلا قرينة كيى واحدة، يسيها الدكتور تمام حسان "وضوح المعنى"، ويسيها اللغويون: "لمن اللب".

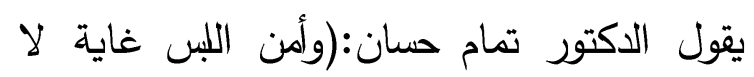
يمكن التفريط فيها، لأن اللغة الملبسة لانتلح

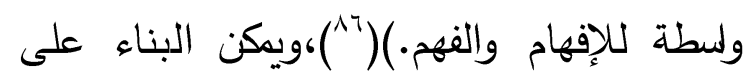

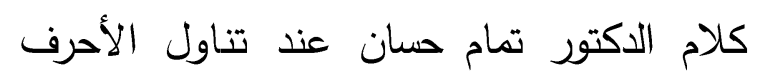

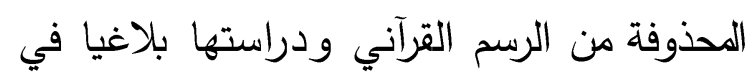

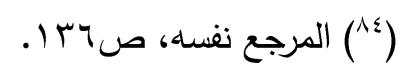

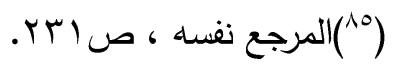

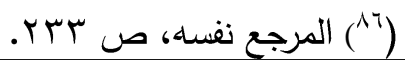

من عناصر لغوية مختلفة تفيد في الكف عن الكن فيان المعنى الوظيفي لهذه الكلمة.)(

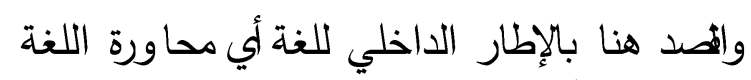

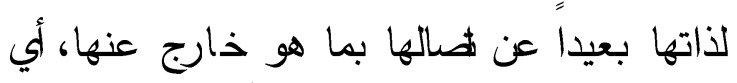

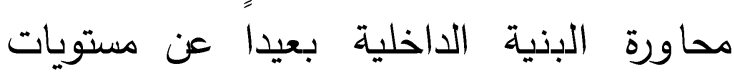

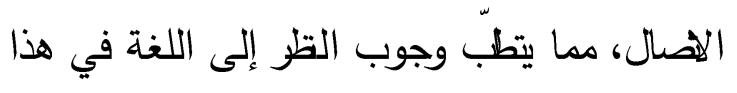

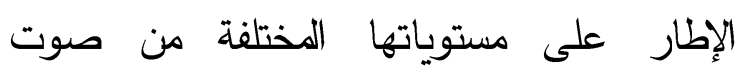
وصرف وتركيب ودلالة وخط. فاض هنا يعتمد

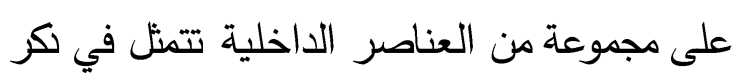
جملة سابقة أو لاحقة.

ويوضح د. تمام حسان القرئن اللظية للسياق بقوله:(السياق كلطريق، لابد له من معالم توضحه.

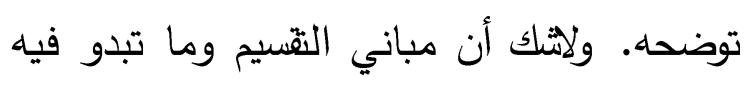
من صيغ صرفية وصور شكلية، وكنلك مباني توني التصرف مع ما تبدو به من لواصق مختلفة، تقدم

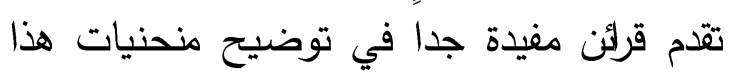

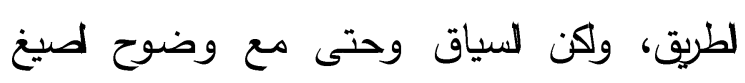
الصيغ واللواصق يظل بحاجة إلى الكثير من القرئن القرائن الأخرى التي تضح بها العلاقات المضوية

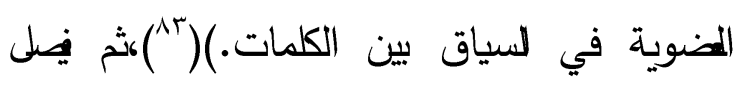
يصل الذكتور تمام مباني هذا التقييم بأنها:

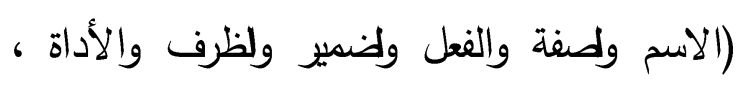

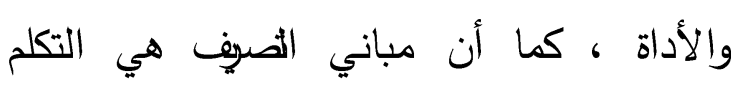

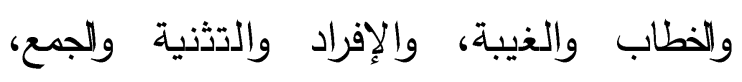

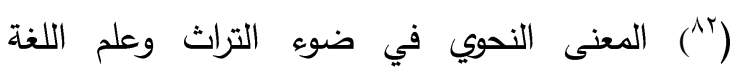

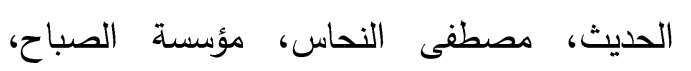

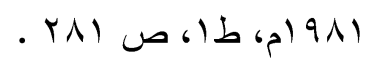

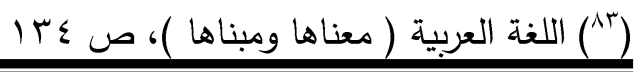


( ففي جض الأحيان لا يمكن العثور على الدليل الدليل التي يرشدنا إلى المعنى لهحيح لصطلح لغزي لإني

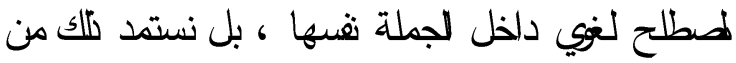
تملك من مجل المحادثة.)(") فيؤي المحيط لخارجي عن الكلام وظيفة الإضاح للكلام نفسه. وقد أدرك القدماء من البلاغيين أهمية هذا الذوع النوع من السياق. ومن أوائل من بينوا ضرورته ضرورته الجلحظ، فقد روى عن بشر بن المعتمر في

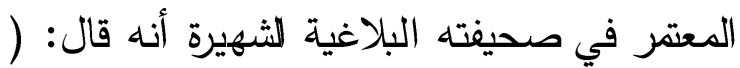

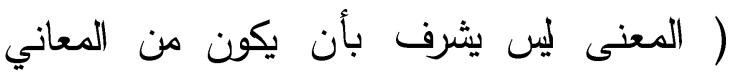

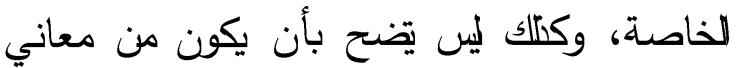

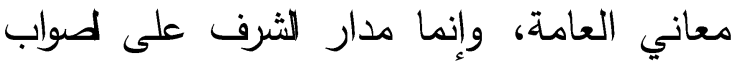

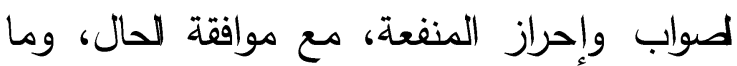

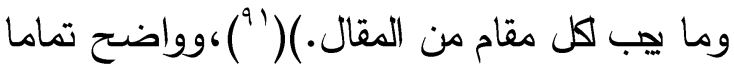
تماما من الكلام التي نقله لجلحظ أن الألفظتستعل تستعل لتنلب الدقام، وأن شرف الكلمة ورفعتها ورفعتها يرجع إلى حسن وضعها في سياقها،

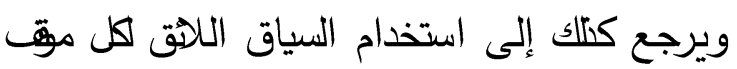
موت وكل شضص. فما يظلب به العلماء لا يظلب به يظلب به لحكام والوزراء، فنلاعن أن يظلب به

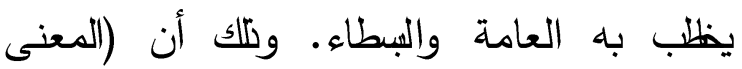
المعجمي ليس كل شيء في إدراك معنى الكلام، الكلام، فثمة عناصر غير لغوية ذات نخل كبير في تحديد المعنى، بل هي جزء أو أجزاء من فئ لئن

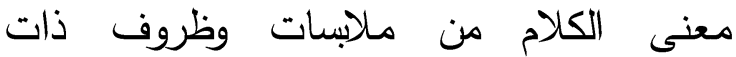

(") دراسات في علم اللغة، كمال بشر، دار غريب،

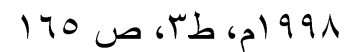

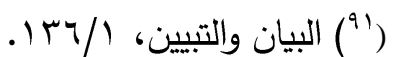

في ضوء السياق، وهو الأهر التي تعنى به هذه الدراسة. والسياق بقرائنه اللظية يقوم بتحديد

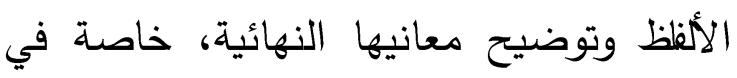
القرآن الكريم . يقول الاكتور محمد عبد الهطب في المطب في كتابه (البلاغة والأسلوبية):(فالكلمات والأسلوبية):(فالكلمات في التركيب تكتب قيمتها قيمتها من مقابلتها لما يسبقها أو يلحقها من

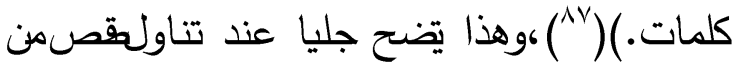

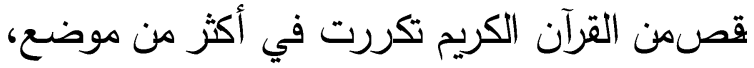

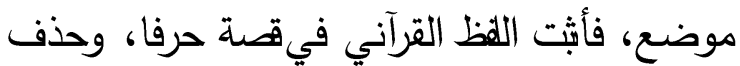
وحذف فس لحرف في الموضع الآخر لفس لألة، الهصة، ومرد تلك كله إلى السياق. ويشير الأستاذ الأستاذ الدكتور مختار عطية إلى أهمية القرائن ودورها في تجلية لسياق فيقول: ( وثلك القرئن

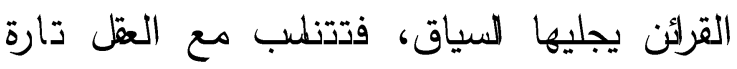

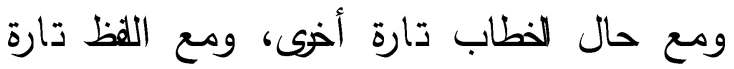
ثالثة، بحيث يتم المعنى. ويكثر هذا لحذف في في

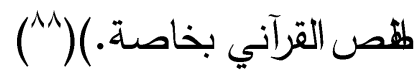

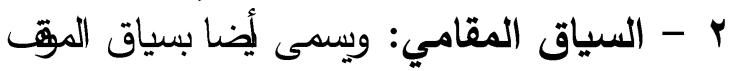

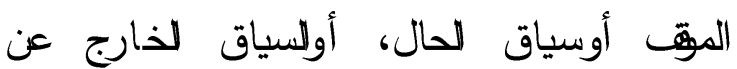

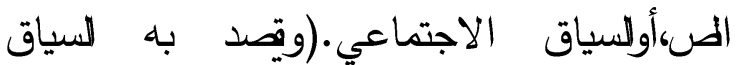
الخارجي للغة، التي يكن أن تقع فيه الكلمة، ويشمل كل ما يمط باللفظة من عناصر غير لغوية

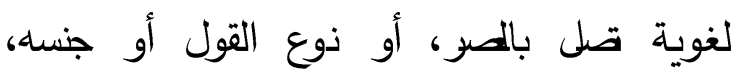

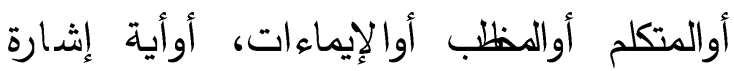

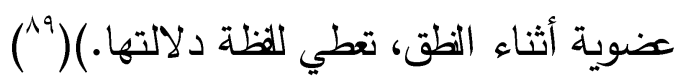

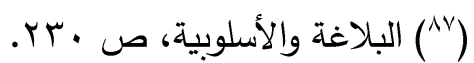

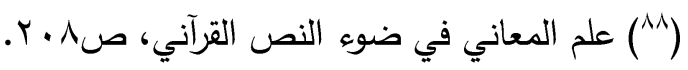

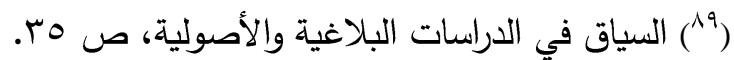


أشار الإمام الثلطبي في الموافقات، إذ يقول:(فإن يقول:(فإن قلنا : إن القرآن نزل بلسان العرب وإنه عربي وإنه لا عجمة فيه، فبمعنى أنه أنزل على لسان معهود العرب في ألفظظها لخاصة

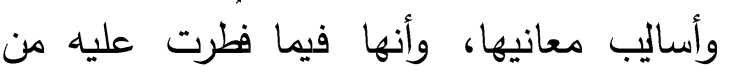
لسانها تظلب بالعام يراد به ظاهره، وبالعام يراد يراد به العام في وجه والخاص في وجها، وبالعام يراد به لخاص، ولظاهز يراد به غير فير في

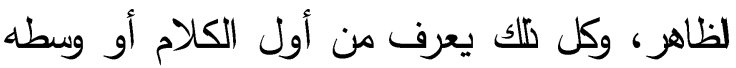
وسطه أو آخره، وأنها تتكلم بالكلام ينبئ أوله

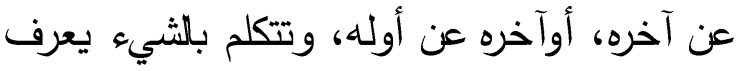

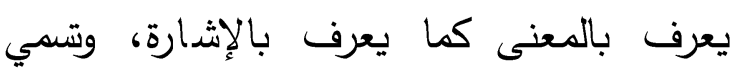
الثيء الواحد بأسماء كثيرة، والأشياء الكثيرة

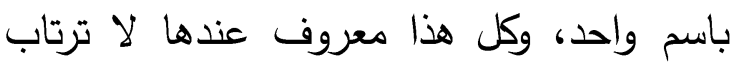

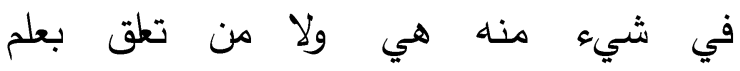
كلامها.)( في (9)

ثخ يضي الإمام الثلطبي مؤكدا كلامه السلق فيقول:(فإذا كان كنلاك؛ فالقرآن في معانيه

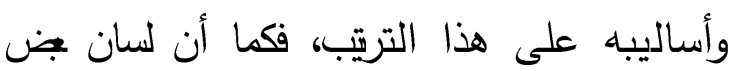

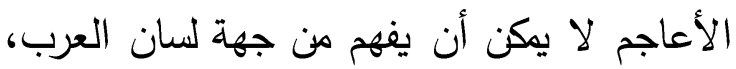

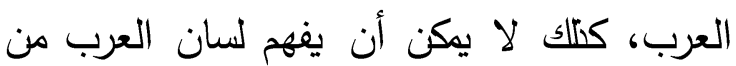

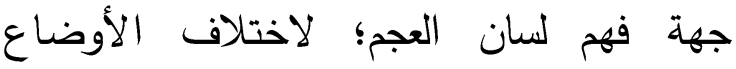
والأسالي، والتي نبه على هذا المأخذ في المسألة

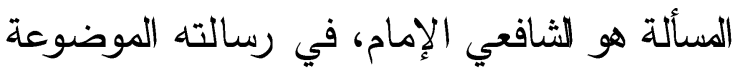

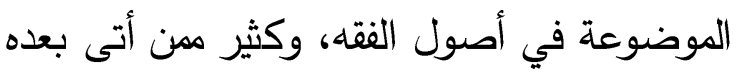
بعده لم يأخذها هذا المأخذ؛ فيب التنبه لتلكئ،

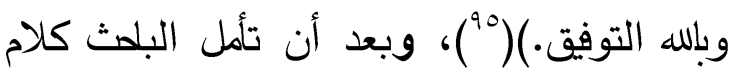

صلة.)( (9) ،ويكن أن يتسع المعنى المألوف لكلمة لكلمة "سياق" (ليثّل الظروف التي تميط بالكتابة لئي

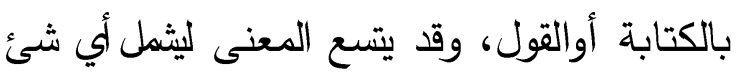
شئ يعود إلى ثلك الصر نراه مناسبا لتفسيره $\left({ }^{9 r}\right)(. "$ إن استخام بض الألفظ يتغير من عصر إلى عصر،

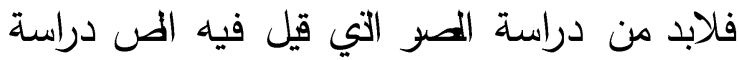
لغوية. وهذا جدول أورده البلث بعد الرجوع

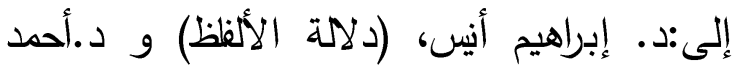

\begin{tabular}{|c|c|c|}
\hline \multicolumn{3}{|c|}{ ختار عمر، (علم الدلالة). } \\
\hline الاستعمال الثقيمي للكلمة & | دلالتها الجديدة & الكلمة \\
\hline 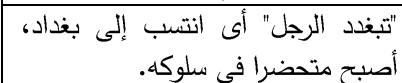 & 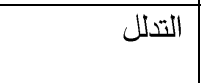 & البغدة \\
\hline ماء، ورقة، عذوبة في الأسنان. & 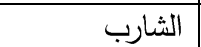 & 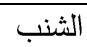 \\
\hline هو ما حرم مسه. & |المرأة & 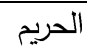 \\
\hline طعام المسافر & 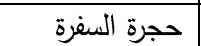 & السفرة - لمغر \\
\hline
\end{tabular}

إن الجدول السلق يبين لنا أهمية معرفة الصر التي النيائ

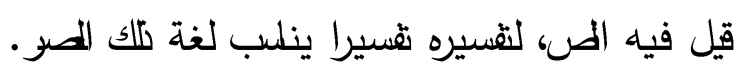
والقرآن الكريم نزل على العرب في زمن معين

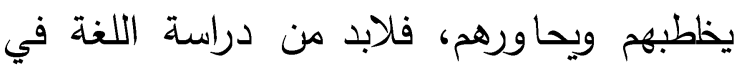
هذا الزمن ليتحق فهم المراد جيدا.

وقد ظلن المسترقون إلى ذلك فأقبلوا على اللغة

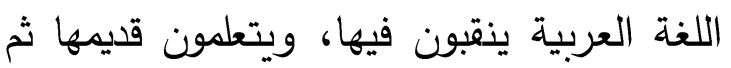

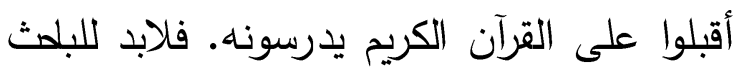

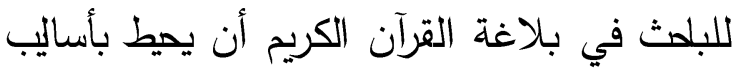
بأسايب العرب في الكلام، فيعرف إثداراتهم إناته

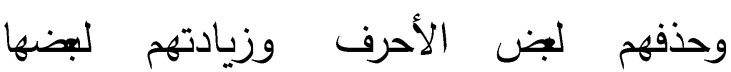
والدلالات البلاغية لهذه الاستعمالات.وإلى هذا لهاتها 
(V) معاني الأحرف المحذوفة التي ستتناولها

\section{اللدراسة :معاني حرف الألف:}

الألف: ( تأليفها من همزة ولام وفاء، وسعيت أَلَفا

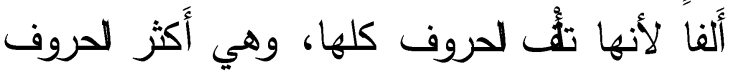

لحروف دخولا في المنظق.)( (4) شخوص حرف الألف ومعانيه : ( ما لَّل سين الأمور والأشياء المتفرقة المختلفة، المختلة، أو آلفها بعد استيحاش ونفور منها، أو الو الأياء

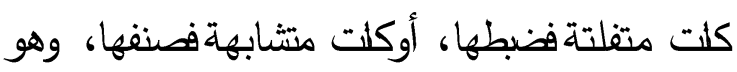
فصنفها، وهو يؤَ بين لحروف لتعطي المعاني.فلله

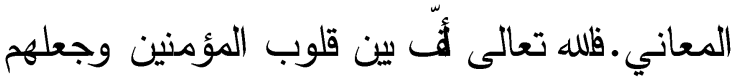
وجعلهم إخوة بعد أن كثت قلوبهم متفرقة وكانوا

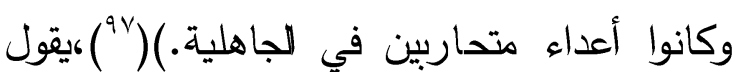

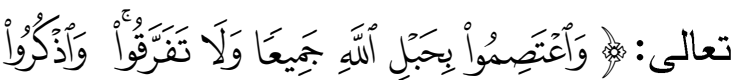

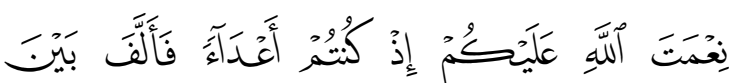

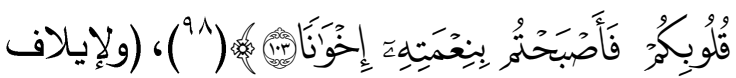
قرش وإلفتهم. فالأف هي كل إئتلاف بين فرقاء

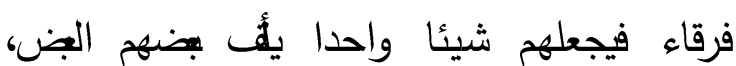

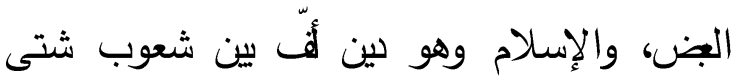

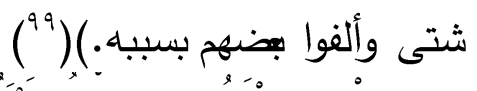

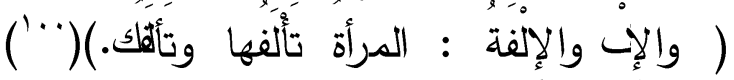

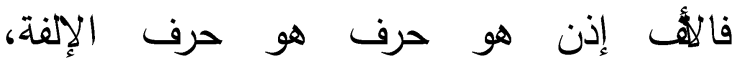

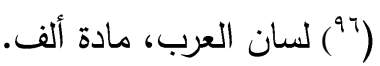

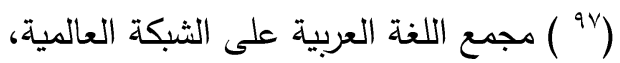

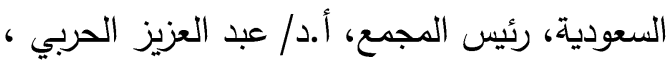
http://www.m-a- : رابط الموقع .arabia.com/site/26984.html

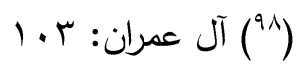
(999) مجمع اللغة العربية على الثبكة العالمية.

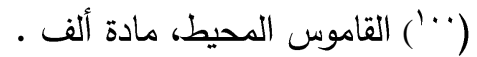

الإمام الشلطبي رأى أنه يؤكد على عدة أمور هي: هي: 1-حتى نفهم أيض لابد أن نعرف الصر التي كب فيه. Y-بعد معرفة الصر، نقوم بدراسة تلك الصر لغة وسياسة وظروفا اجتماعية. r-حتى نفهم القرآن الكريم فهما صحيحا، وكنلك الحيث الذيوي الثرفي، لابد أن نفهمه كما فهمه لمدابة الأولون. ع-ننزل هذا الفهم السليم على الصر التي نعيشه، ونقي الثبيه عليه فنفهم مرادالله يقينا. ه-السياق القرآني له دوره في فهم مراد الكلام على وجها لهحيح.

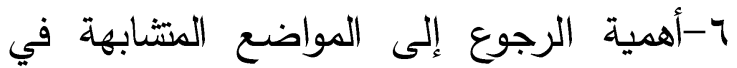

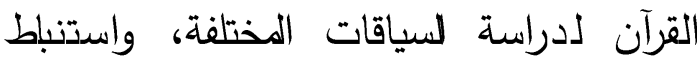
الفوائد البلاغية من اختلافات السياق. إن السياق المقامي يكثر في آيات القرآن الكريخ

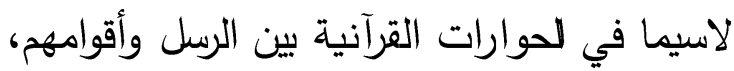
والمقام هو التي يوضح لنا البلاغة القصودة من حذف بض الأحرف من كلمات الرسم القرآني.

ولما كانت هذه الاراسة تتناول الأحرف المحذوفة في الرسم القرآني بالدراسة البلاغية، فمن المفيد أن يتناول الباحث معاني هذه لرانه الأحرف ( الألف والواو والياء، واللام، والنون ) في محورين:المحور الأول: معاني لحرف.

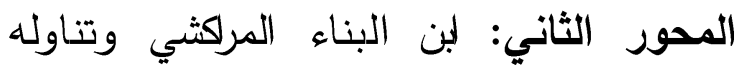
للأحرف المحذوفة في عنوان الداليل. 
القليل وافرا، وتجعل الواحد وارفاء،وتجعل الفرش

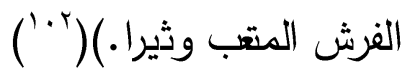
معاني مرف الياء :الياء: (لحرف الثلمن والعثرون من حروف الهجاء، وهو مجهور وأَشباء وأَشبه بالحروف المتوسطة، ومخرجه من بين أول

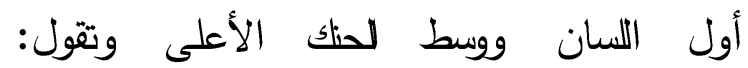
يَّيَّ ياء حسنة: كتبتها وتكون الياء أَصلية كما ولئ في اليمين واليسار، وزائدة كما في الكيبير

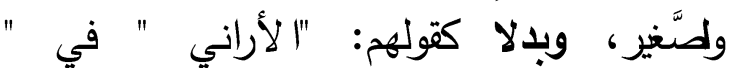

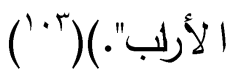

شخوص حرف الياء ومعانيه:(الياء هي الضو أو المرحلة الأشد والأكثر تأثيرا من غيرها، فهي الئه فهي المرحلة التي تغير ماقبلها أو تحل محلها. فالنوم يتغير لليقظة، واللين لليس، والعمران

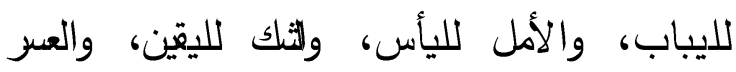

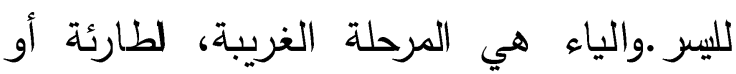
الأثَط بين نظرائها: كاليتم على الأطفال وهو أمر لئر

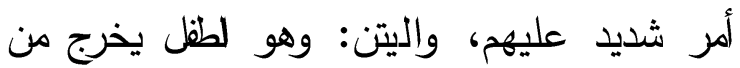

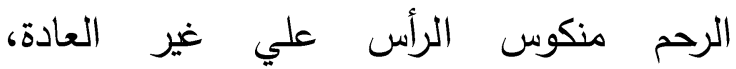
واليراعات: وهي الحشرات للضيئة وهي نادرة نادرة وغريبة. واليوم: وهو المرحلة الأثد والثي

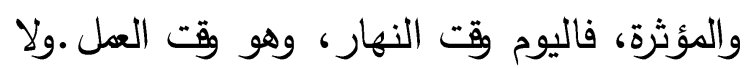
العل.ولا يككر القرآن اليوم إلا في الوقت لجل

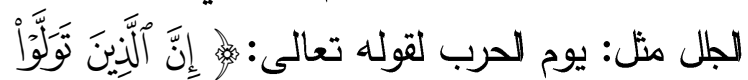

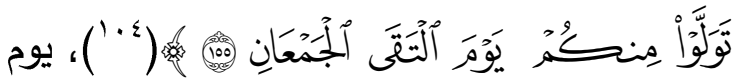

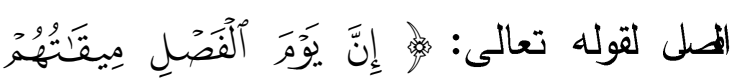

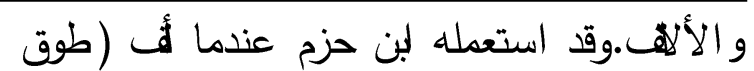

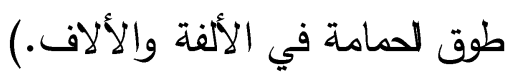

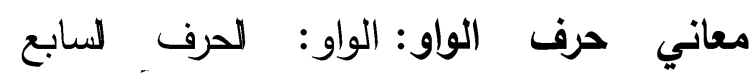
والعشرون من حروف الهجاء، وهو مجهور وأشبه وأشبه بلحروف المتوسطة، ومخرجه من بين أول

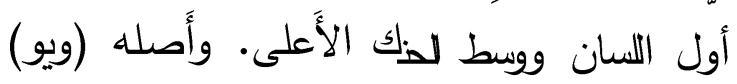

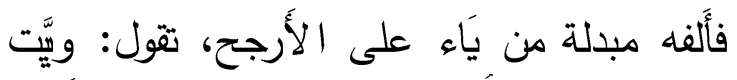

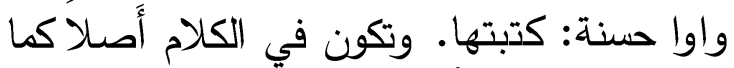

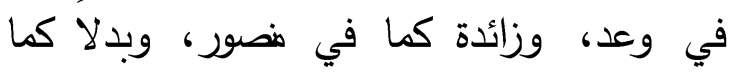

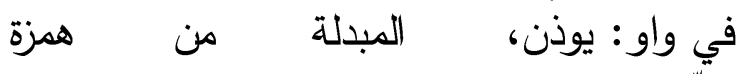

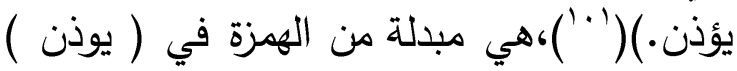
وأمثالها، في بذ القراءات واللهجات. شخوص حرف الواو ومعانيه:(حرف الواو يعني: الواصل، الوسط، الواحد أو الوسيلة. فالواو

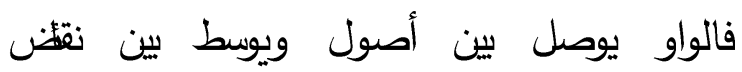

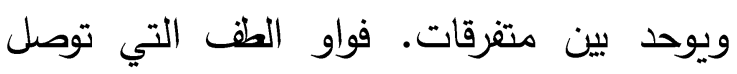
الشيء بمعطوفه، مثل: جاء زيد وعمرو. والواو والواو التي توحد بين المتفرقات وتوصلها ببضهاه بهضها وتجعلها كثيء واحد، مثل: إفريقيا وآسيا وآسيا وتوحد كلظ واحد بدخول الواو فنقول: أفروآسيا. الواو: الوفاة وهو وصول لحئ لحي لتمام أيام حياته. الواو: الواقي وهوما يتوسط لئ لين الشيء ومايضره. مثل: الوسادة وهي المخدة تتوسط التواته تتوسط فتوقي الرأس عند النوم. الواو: الوكاء وهو وهو ما يتوسط بين الشيء والأرض، ئ يتكأ عليه

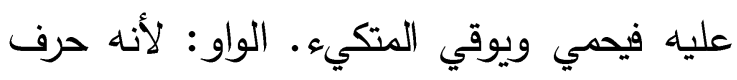

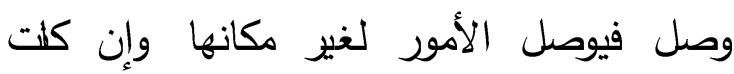

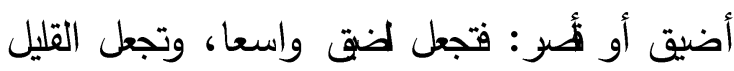

(ץ+1') مجمع اللغة العربية على الثبكة العالمية.

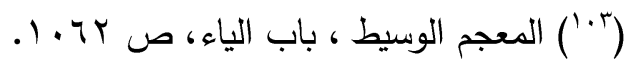




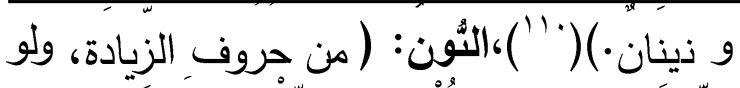

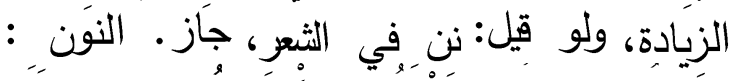

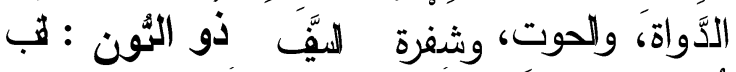

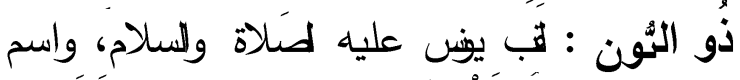

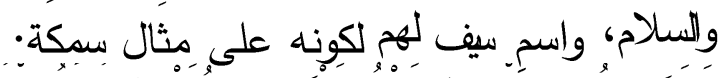

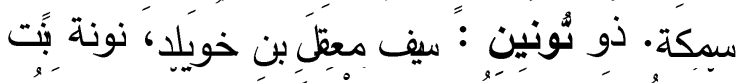

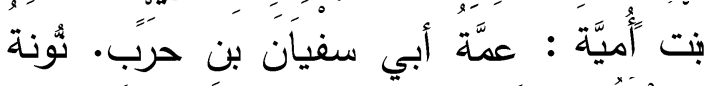

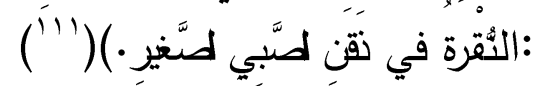

شخوص حرف النون ومعانيه :(النون هي ما

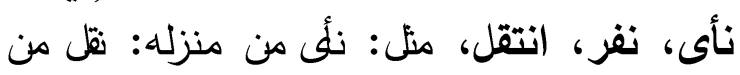

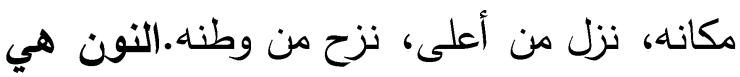

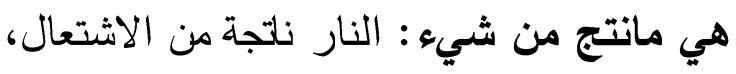

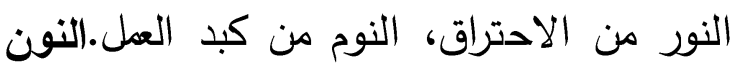

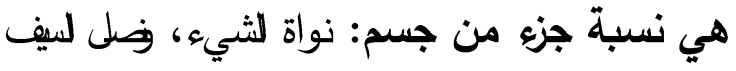

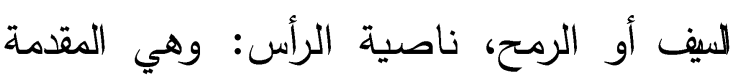

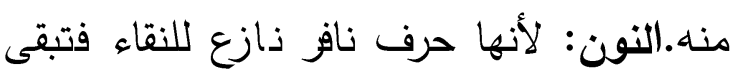
دوما نقية أنيقة من غير اختلاط، مثل: النظافة:

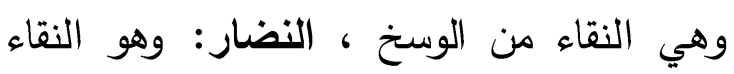

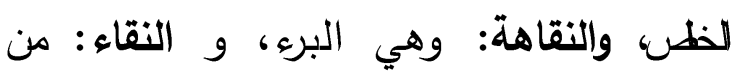
الثبهات.وشخوص النون في الإناث أكثر من النقاء

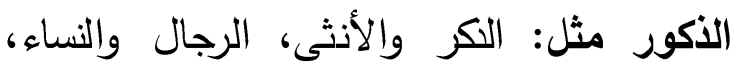

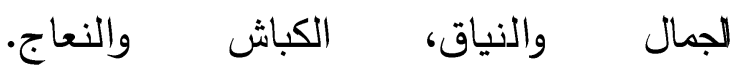
وكل مملكة نونية تكون الإناث فيها سائدات كالنحل كالنحل والنمل، والعنهب والنباتات، ودائما الإناث الإناث أكثر من الذكور لأن النكر الواحد يكفي

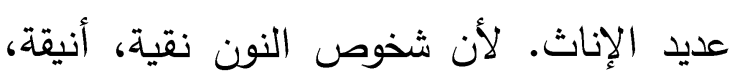

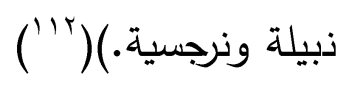

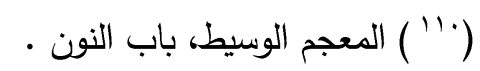

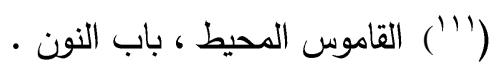

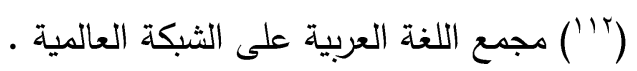

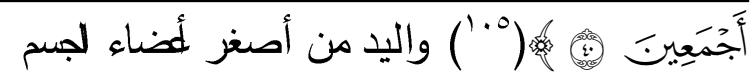
الجم لظاهرة مقارنة بالرجل، ولكنه أثنطها، والآية أصغر من السورة.إن شخوص الياء صغيرة

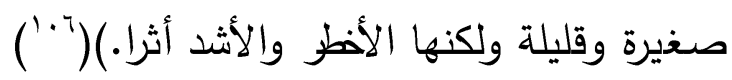

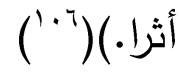
معاني حرف اللام :اللام: (من لحروف المجهورة المجهورة وهي من لحروف اللثق، وهي ثلاثة

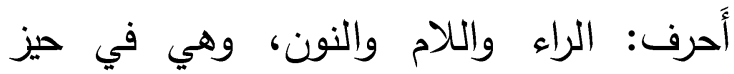
واحد، وقد ذكرنا في أَول حرف الباء كثرة دخول

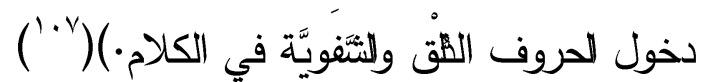

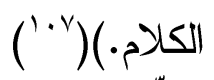
اللام:(هو لحرف الثلث والعثرون من حروف الهِجاء، وهو مجهورِ متوسط، ومخرجه من طِرَف

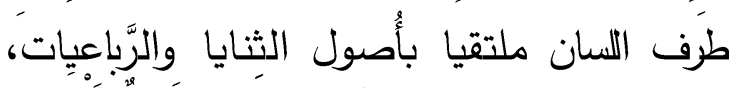

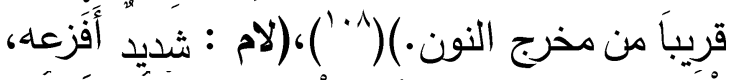

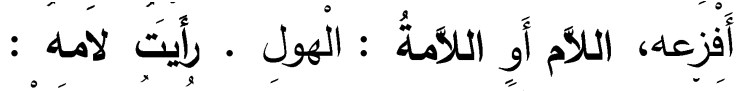

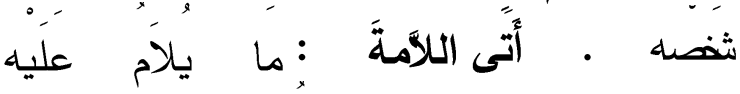

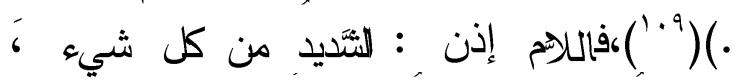

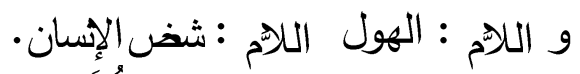

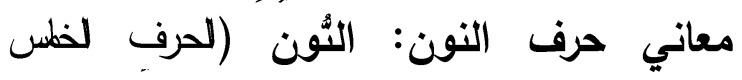

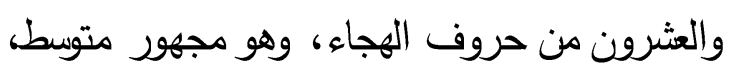

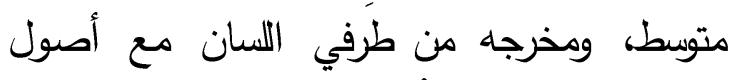

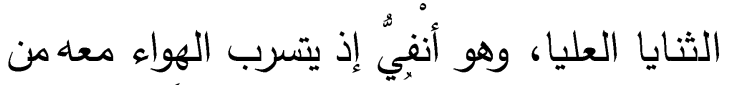

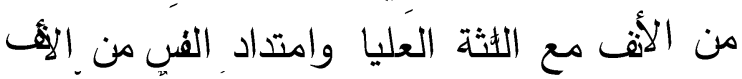

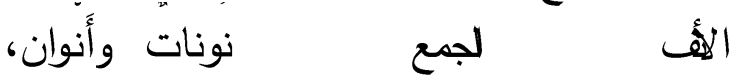

$$
\text { (1.0) }
$$

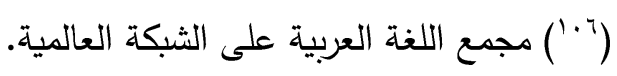

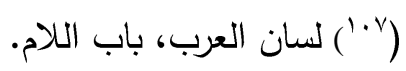

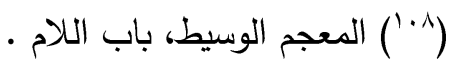

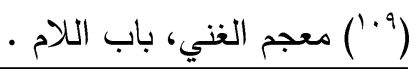


الجهة آخر لحروف كلها، وهي مع كل حرف في في مقطعه، فلأجل تلك لم يجعل للهمزة صدورة في في الخط. وإذا عضدت في موضع في لخط فاجن فإنما

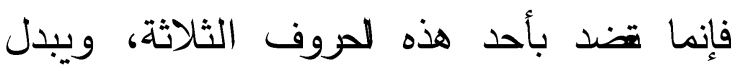

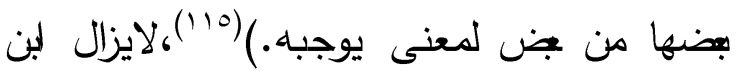

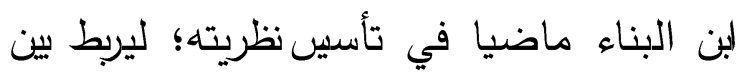
معاني بقاء الأحرف ومعاني حذفها من الرسم

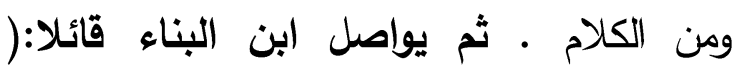
ولأحوال هذه لحروف مناسبة لأحوال الوجود لباء هل بها بينهما ارتباط به يكون الاستدلال.

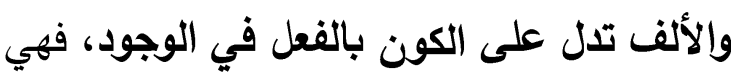

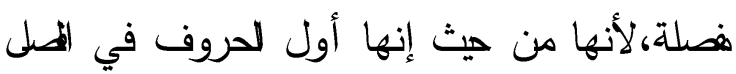

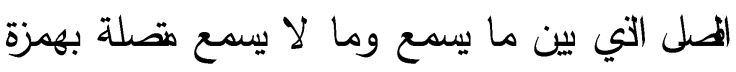

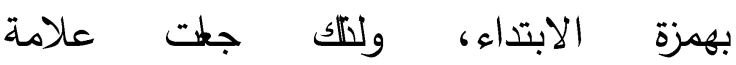

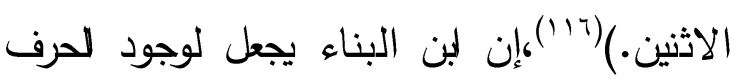

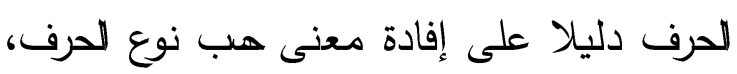

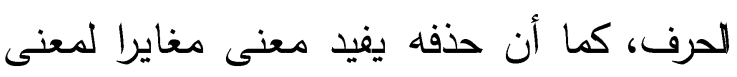

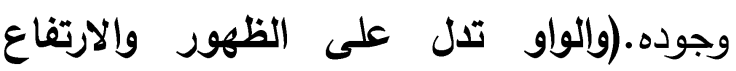

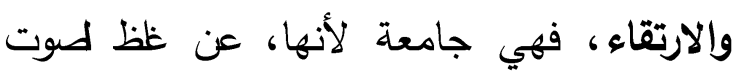

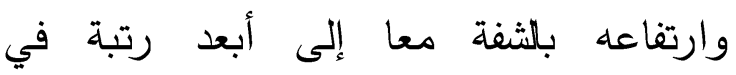

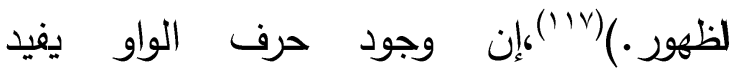
الارتفاع ولظهور، وحذفه يفيد لخفاء.(والياء

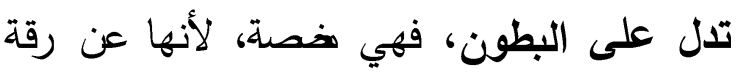
رقة لصوت وانخفاضه في بلطن الفم.ومما يوضحه في الفها يوضحه لك عن قرب، اعتبار حروف المد واللين

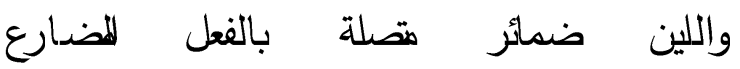

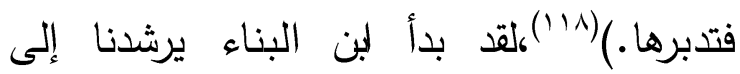

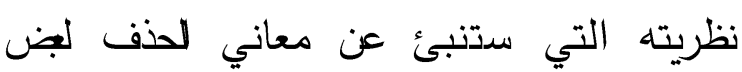

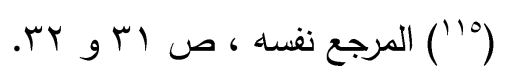

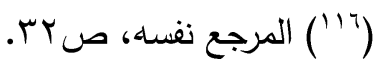

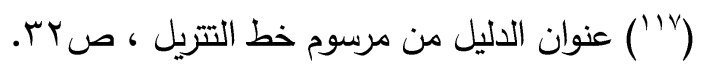

(1 ) ابن البناء المراكشي وآراؤه في الحذف من

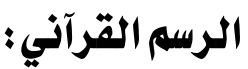

يقول لبن البناء المركثي: (إن الخط المصوس له

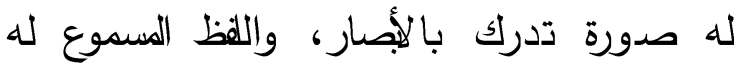

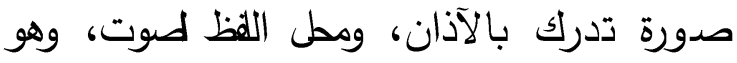

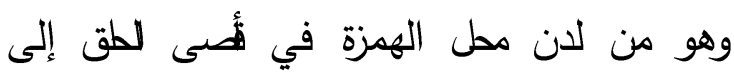

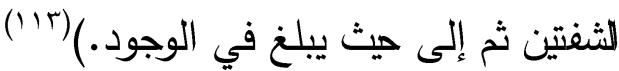

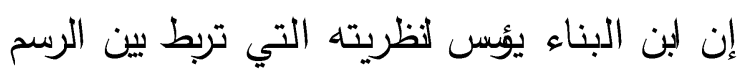

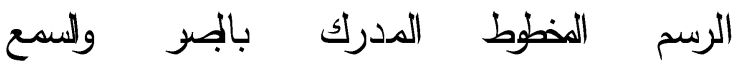

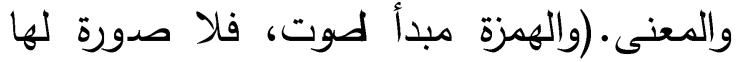

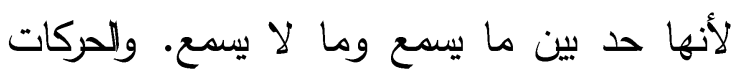

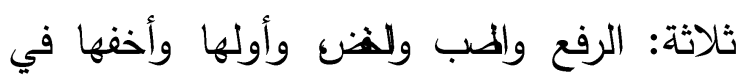

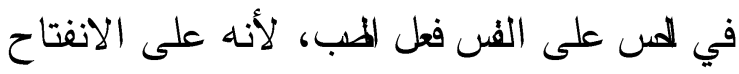

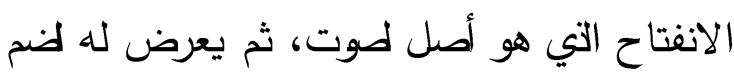

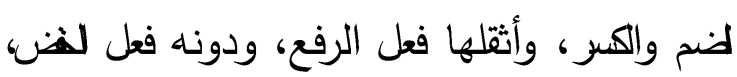

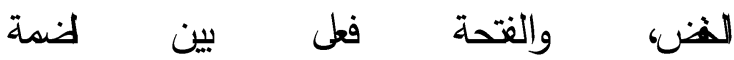

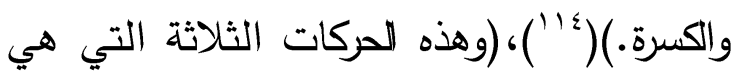

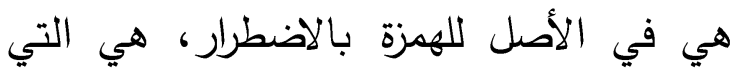
تلقى على سائر لحروف الساكنة بالاختيار . فإذا لإنا

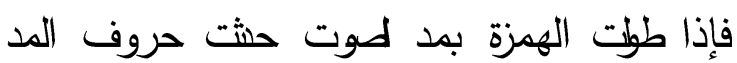
المد واللين الثلاثة تابعة للحركات الثلاثة، فلها صدورة ظاهرة في السمع وهي: الهأل والواو والياء. فهذه لحروف الثلاثة من هيث ثلت فئ

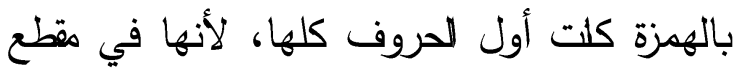
مقطع الهمزة، والحروف بعدها في مقاطع أنفها،

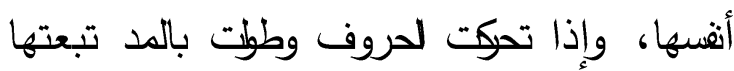

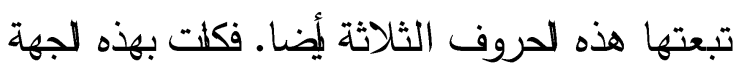

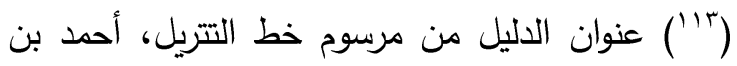
البناء المراكثي (أبو العباس)، تحقيق: هند شلبي،

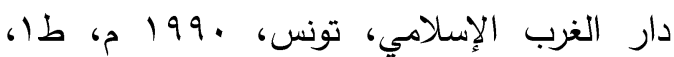

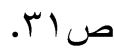

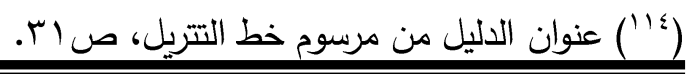


الأهل يدل على قنمي الوجود. والواو على قم

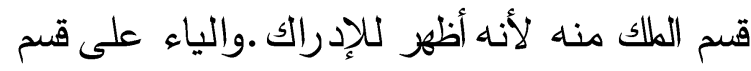

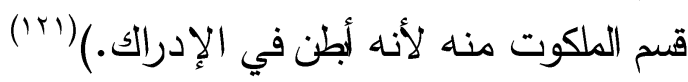

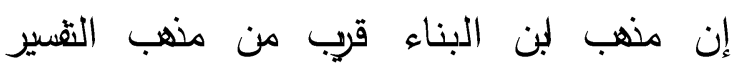
الإثشاري، إلا أنه يبنى على العلم ويبتعد عن من لن الغلو.

ثم يتحدث لبن البناء عن الأحرف المحذوفة بثكل

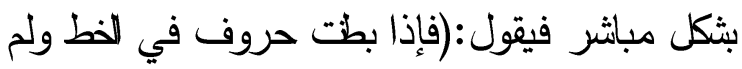

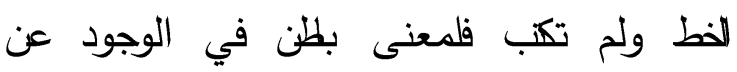

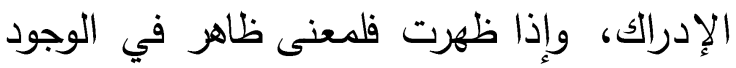

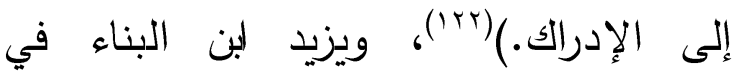
العناصر التي تتناولها نظريته، فيتناول بعد لإلناء

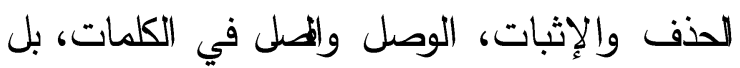
بل ويتناول تغير رسم الكلمة بتغير موقعها،

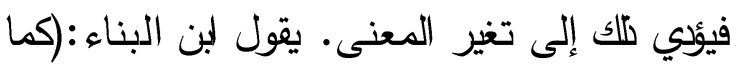

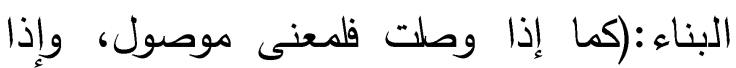

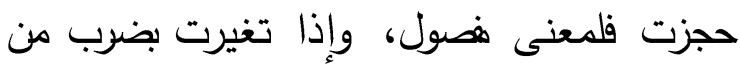

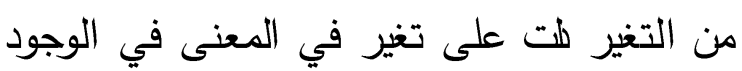

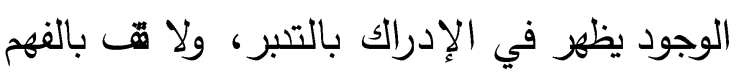

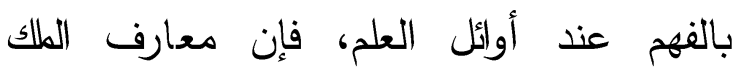

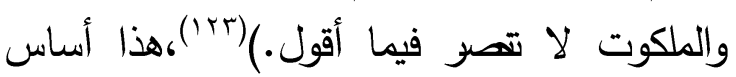
أساس نظرية لبن البناء المركثي، وسيظهر تلبر

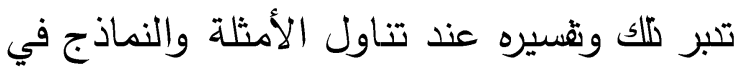
في ثنايا هذه الدراسة.وسيضح أن أصول هذه ولني النظرية موجود عند الsفسرين والعلماء النين سبقوا

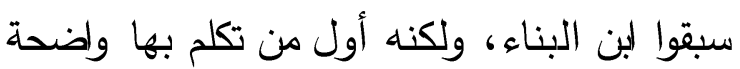
واضحة هضلة، ثم تبعه من جاء بعده من العلماء.

العلماء.

("r") عنوان الدليل من مرسوم خط التتريل ، ص ع ب.

$$
\text { (المبr) }
$$

الأحرف، وتلك بكر دلالات هذه الأحرف و بيان بيان فعلها و أثرها في الوجود. وييى لبن البناء أن المعاني ترد إلى بايين كبيرين:

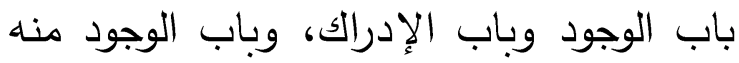

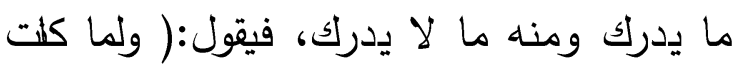
المعاني تعتبر اعتبارين: تعتبر من باب الوجود

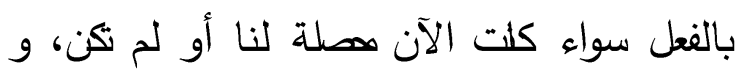

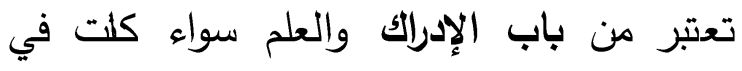

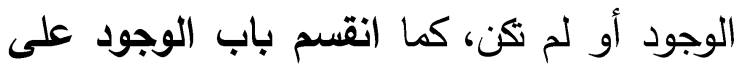

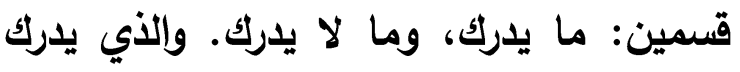
على قسمين: 1

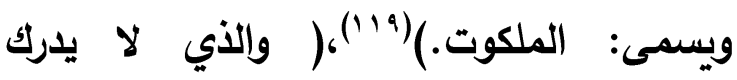
نتوهمه على قسمين: ما ليس من شأنه أن لأن يدرك فهو معاني أسماء الله وصفة أفعاله، من هيث من مئه هيث أسماؤه وأفعاله فإنه انفرد بعلم لتلك سبحانه

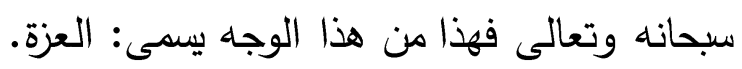
العزة. وما من شأنه أن يدرك هن لئ لم نصله لئه بإدراك، وهو ما كان في الدنيا ولم ندركه ولا لانها

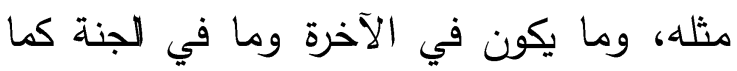

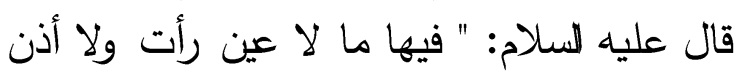

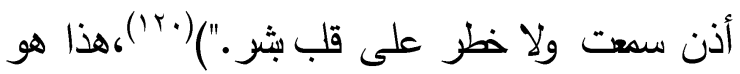

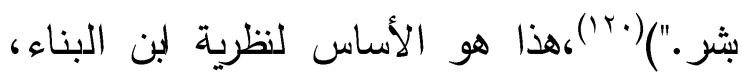
والأحرف المحذوفة في القرآن مردها عنده إلى الهـ لهن

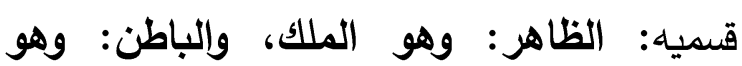

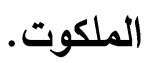
ابن البناء يفصح عن نظريته فيقول: (والتنزيل

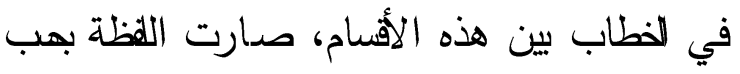
بهب تلك مشتركة في الاعتبار بين البابين وأقَسام وأقسام الوجود، فاحتلبت إلى فرقان. فيجعل الهُ لئل 
فيقول:(وقال الزخثي في قوله : "أيم الله" في اليبياز القسم:إنها"أيمن" التي تستعمل في القسم، حقت نونها نونها. ومن هذا الترخيم، ومنه قراءة بضهم:"يا بضهه:"يا ملك". "يا مال" على لغة من ينتطر،

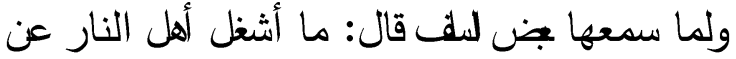

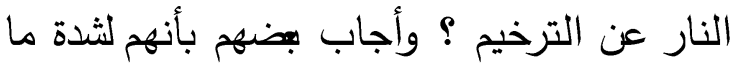

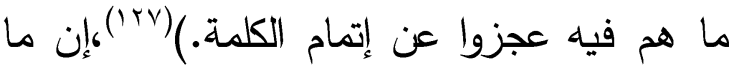
ذكره الزركثي في برهانه يخل فيما تعنى باه هذه

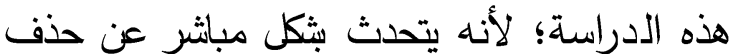
حذف بض الأحرف من الكلمة، والفائدة البلاغية البلاغية لهذا لحذف. كما أشار الزركثي إلى الى الى الثية استخدام العرب لهذا لحذف في لغتها، وعليه جاء حسث الرسول صلى الله عليه وسلم :( كفى في الفيه كفى بالسيف شا.)( و قبل الزركثي تحدث أئمة اللغة وعلماؤها عن هذا الحذف، ومن ذلك:

"قول سيبويه: ( وسمعت من العرب من يقول: ألا

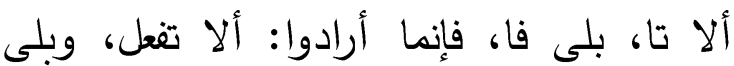

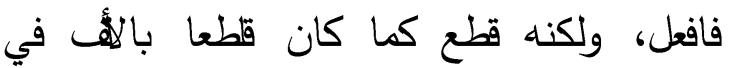

*قوقول لبن جني: ( إن العرب إذا أخبرت عن الثيء غير معتمدته، ولا معتزمة عليه أسرت إن إنت

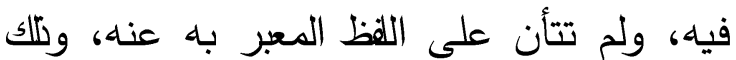

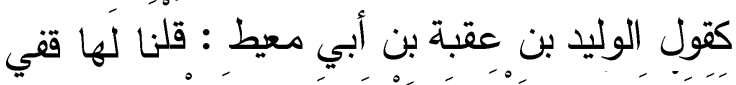

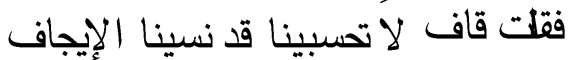

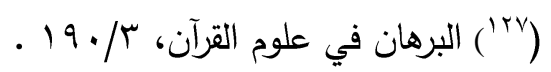

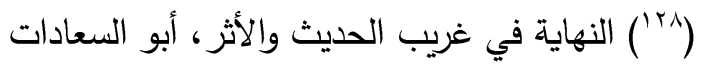
المبارك بن ححم (ابن الأثثر )، تحقيق: طاهر

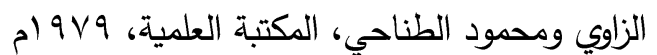

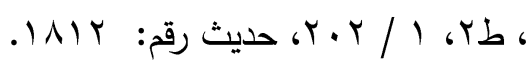

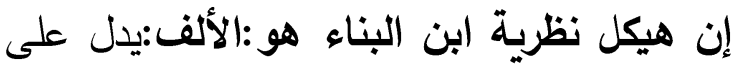

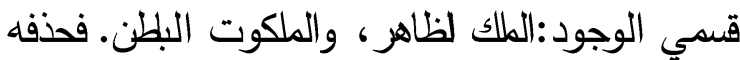
يرد إلى تلك.الواو: تدل على قسم الطلك والظهور والعلو، وحذفها يرد إلى الآخفاض.الياء: تدل على الملكوت البطلن، وحذقها يرد إلى تلك.

\section{( ) (9 ) وقفة لابلد منها:}

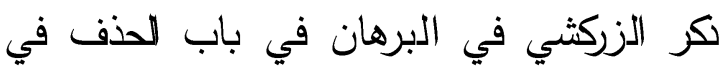

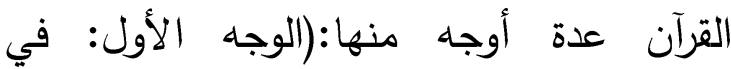
فوائده، والثاني: في أسبابه، والثلث: في أدلته، التهان

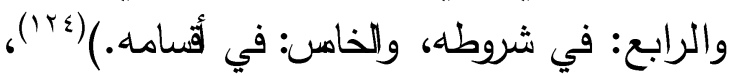

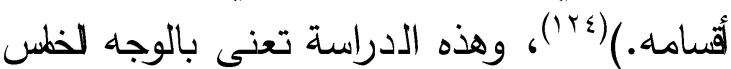

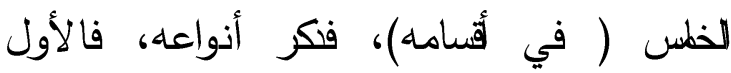

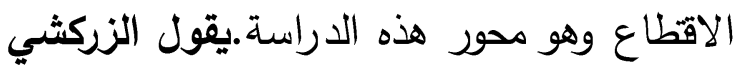

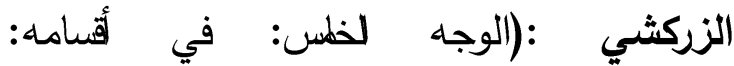
الأول الاقطّاع، وهو لكر حرف من الكلمة وإسقط الباقي، كقوله: "درس المنا بمتالع فأبان"، أي: الهنازل، وأنكر صلصب"الهثل السائر"ورود هذا النوع في القرآن العظيم،وليس كما

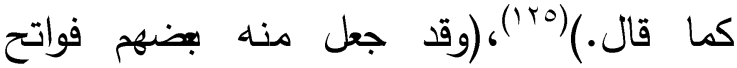

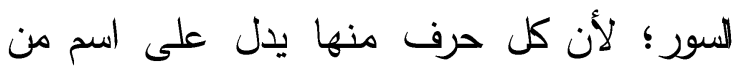

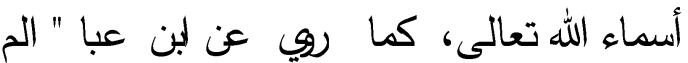

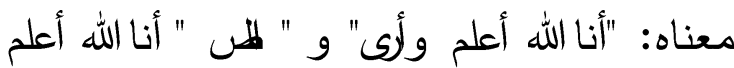

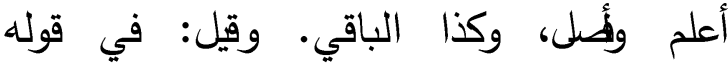

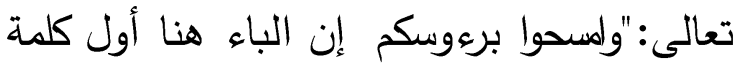

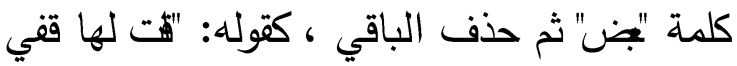
قفي لنا قلت قاف" أي: وقت، وفي لحيث: "كفى التى

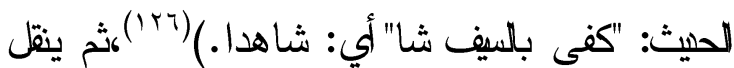
ينقل الزركثي عن الزخخثي ما يضد كلامه

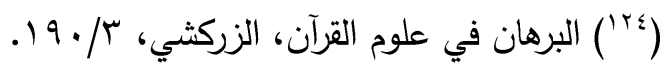

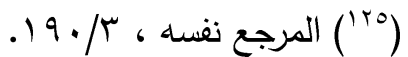

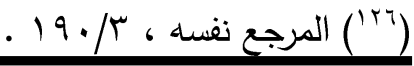


كثيرة من جولب إعجاز القرآن الكريم. ( إذ يرجعه يرجعه بهضه إلى ما يحتويـا القرآن من تنبؤات

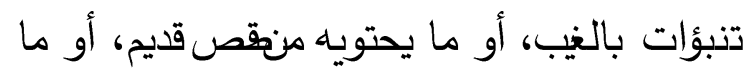
أو ما ذهبوا إليه في قضية لهرفة وأن الله صرف دأن صرف العرب أن يأتوا بمثله، ويتوسط هذه السبل السبل جميعا ما اسثقر لاى العماء من أن إلهجاز إعجاز القرآن إنما يتأتى في المقام الأول عنطريق طريق بلاغته وبيانه وسحر خطابه وتفرد

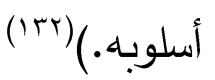

( ) (1 ) الطريقة التي سينهجها الباحث: 1 الاستثهاد والدراستة. r - إظهار الكلمة مطل الدراسة. r - بيان سبب النزول إن احتاج إليه البث. ع - عرض آراء المفسرين النين عنوا بلجب البلاغي، كالزمخثري وأبي حيان والرلني، والنسفي ومحيي اللين الدروي، ولطبي واليضلوي، ولبن عاشور و وابن عية،

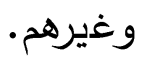

0 - تناول الكلمة التي بها لحرف المحذوف بالدراسة البلاغية.

7 - ترجيح ما يؤيد الرئي التي اخترته من أقوال المفسين والبلاغيين مع بيان للبب.

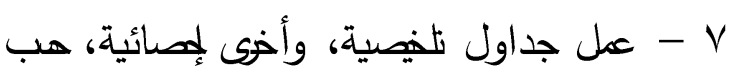
احتياج الدراسة.

(rr (r) علم البيان (المصطلح-الثاهد-الدلالة)،مختار

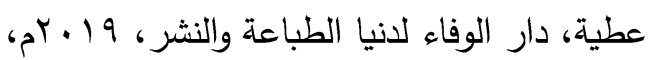

معناه: وقت، فاقصرت من جملة الكلمة على حرف اهن

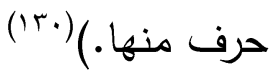
إن منهب لحذف منهب معروف مشهور عند العرب، وبـه صـح النقل عنهم. قال الزركثي في برهانه: الذوع لخطس والعشرون: والعثرون: علم مرسوم لخط: (واعلم أن اللثيء في للثيء في الوجود أربع مرلب: الأولى، حقيقته حقيقته في نفسه، والثانية، مثاله في الأه، وهذان لا يختلفان باختلاف الأمم. والثالثة، اللفظ الدال على المثال الذهني والخارجي، والرابعة، الكتابة الدالة على اللفظ . . وهذان قد يختلفان باختلاف الأمم، كاختلاف اللغة العربية والفارسية، ولخط العربي والهني؛ ولهذا صف صف الناس في الخط والهجاء؛ إذ لا يجي على على حقيقة اللفظ من كل وجه.)(اب")، إن حسيث الزركثي عن علم مرسوم خط للهف يتقارب مع يتقارب مع حيث لبن البناء المركثي، فالزركثي هري فالزركثي يص على أن الفظ لا يجي على حقيقته حقيقته من كل وجه، وابن البناء يتحدث عن ما يدرك و ما لا يدرك، ويتحدث عن معارف الملك من الملك والملكوت التي لا تهصر . لمدرك ولما كثت هذه الدراسة تهدف إلى إظهار جلب من من جولب إلجاز القرآن الكريم يق بالرسم القرآني، فن لجنير بالكر أن يشير البلمث إلى أن

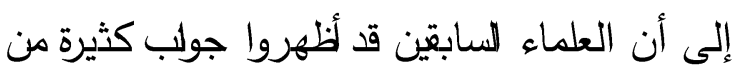

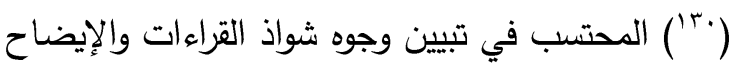
عنها، عثمان بن جنى، تحقيق : عبد الفتاح

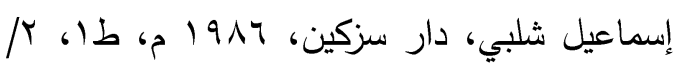
$r \cdot \Lambda, r \cdot \varepsilon$

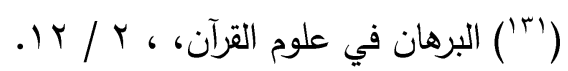

